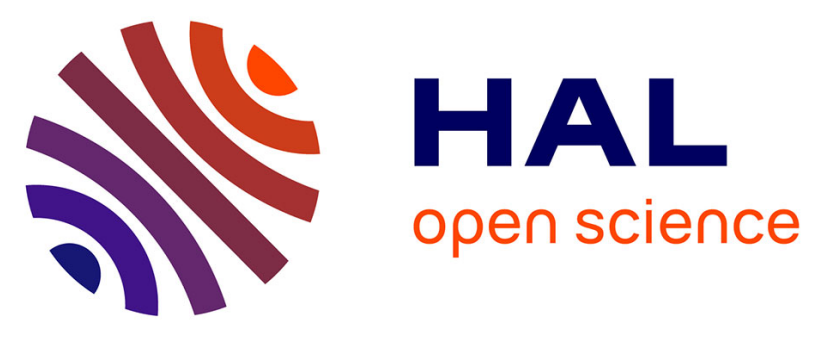

\title{
Effects of calcium complexation on heparin-like disaccharides. A combined theoretical, tandem mass spectrometry and ultraviolet experiment
}

Daniel Ortiz, Quentin Enjalbert, Luke Macaleese, Philippe Dugourd, Jean-Yves Salpin

\section{To cite this version:}

Daniel Ortiz, Quentin Enjalbert, Luke Macaleese, Philippe Dugourd, Jean-Yves Salpin. Effects of calcium complexation on heparin-like disaccharides. A combined theoretical, tandem mass spectrometry and ultraviolet experiment. Rapid Communications in Mass Spectrometry, 2015, 29 (12), pp.11351144. 10.1002/rcm.7204. hal-01221299

\section{HAL Id: hal-01221299 \\ https://hal.science/hal-01221299}

Submitted on 8 Oct 2018

HAL is a multi-disciplinary open access archive for the deposit and dissemination of scientific research documents, whether they are published or not. The documents may come from teaching and research institutions in France or abroad, or from public or private research centers.
L'archive ouverte pluridisciplinaire HAL, est destinée au dépôt et à la diffusion de documents scientifiques de niveau recherche, publiés ou non, émanant des établissements d'enseignement et de recherche français ou étrangers, des laboratoires publics ou privés. 


\title{
Effects of calcium complexation on heparin-like disaccharides. A combined theoretical, tandem mass spectrometry and ultraviolet experiment.
}

Daniel Ortiz ${ }^{1,2}$, Quentin Enjalbert ${ }^{3.4}$, Luke MacAleese $e^{3.4}$, Philippe Dugourd ${ }^{3.4}$, Jean-Yves $\operatorname{Salpin}^{1.2}$

1) Université d'Evry Val d'Essonne - Laboratoire Analyse et Modélisation pour la Biologie et l'Environnement - Boulevard François Mitterrand - 91025 Evry - France

2) CNRS- UMR 8587.

3) Université Lyon 1- Institut Lumière Matière, 5 rue de la Doua, 69622 Villeurbanne cedex, France

4) CNRS- UMR 5306.

\begin{abstract}
:
In order to shed light on the influence of $\mathrm{Ca}^{2+}$ metal cation on the structure of heparin-like (Hp) disaccharides, we have explored the gas-phase structures of both $[\mathrm{Hp},-2 \mathrm{H}]^{2-}$ and
\end{abstract}


$[\mathrm{Ca}(\mathrm{Hp}),-3 \mathrm{H}]^{-}$ions by coupling experimental and theoretical methods. The goal of this work was to (i) provide new evidence of the metal influence on the Hp structure, which can have important biological consequences, and (ii) to study the usefulness of metal complexation for the analytical distinction of Hp isomers. Collision-induced dissociation (CID) and ultraviolet photo dissociation (UVPD) fragments, as well as optical spectra recorded in the gas phase for both $[\mathrm{Hp},-2 \mathrm{H}]^{2-}$ and $[\mathrm{Ca}(\mathrm{Hp}),-3 \mathrm{H}]^{-}$complexes were compared for I-H, II-S and III-S isomers of Hp. In the case of CID fragmentation, a change in the fragmentation pattern was observed upon calcium complexation, with respect to deprotonated Hp. Remarkably, when optical spectra are compared in the UV range, the metal effect onto the carboxylic group absorption can be detected by an unambiguous blue-shift $(\sim 20 \mathrm{~nm})$.

\section{Introduction}

Heparins (Hp) sulfated polysaccharides, which are composed of repeating dissacharide units of hexauronic acid linked $(\alpha 1 \rightarrow 4)$ to a hexosamine residue, belong to the family of 
glycosaminoglycans (GAGs). Sulfation can occur at the 6-O and/or N-positions of the gluscosamine, as well as the 2-O position of the hexauronic acid. GAGs usually exist as the O-linked side-chains of proteoglycans, associated with numerous important physiological activities, ${ }^{[1]}$ generally associated with their interaction with diverse proteins. ${ }^{[2-4]}$ In some cases, this interaction can be modified by the binding of natural metal ions to these Hp/protein complexes. The role of metals is usually associated with affinity, specificity and stability of these complexes. ${ }^{[5-8]}$ In spite of their importance, the mechanism by which metal cations modulate Hp activity in Hp-protein complexes is mostly unknown.

One of the most studied Hp/protein system is the Annexin V- Hp interaction. Annexin V is an anticoagulant protein involved in a wide range of functions in eukaryotes, ${ }^{[9,10]}$ which exhibits high-affinity calcium-dependent interactions with GAGs. ${ }^{[11]}$ Physiological $\mathrm{Ca}^{2+}$ induces conformational changes in Hp that are necessary for the Hp-protein interaction. Evidences of $\mathrm{Hp}-\mathrm{Ca}^{2+}$ binding have been measured by polarimetry, ${ }^{[12]}$ Nuclear Magnetic Resonance (NMR), ${ }^{[13,14]}$ InfraRed spectroscopy (IR), ${ }^{[15,16]}$ atomic absorption ${ }^{[17]}$ or ion mobility coupled to mass spectrometry (IMMS). ${ }^{[18]}$ In all these studies, results indicate that the metal interacts with the carboxylic acid. It was also found that both the NHY and the 6-O-sulfate groups of the glucosamine residue are essential for the interaction of $\mathrm{Hp}$ with $\mathrm{Ca}^{2+} \cdot[5,14]$

Structural characterization of sulfated $\mathrm{Hp}$ benefited from the development of mass spectrometry techniques applied to oligosaccharides. ${ }^{[19-27]}$ Nevertheless, the fragmentation behavior of sulfated Hps has proven difficult to analyze. Sulfate group losses prevent full structural characterization by $\mathrm{CID}^{[28]}$ Alternative ion-dissociation techniques such as electron-detachment dissociation (EDD), ${ }^{[29]}$ electron-transfer dissociation (ETD) $\left.{ }^{[30,} 31\right]$ electron-induced dissociation (EID), ${ }^{[32]}$ electron capture dissociation $(\mathrm{ECD})^{[31]}$ and electron photodetachement dissociation (EPD) ${ }^{[33]}$ have recently been developed. These techniques promote alternative fragmentation pathways which provide complementary structural information with respect to conventional CID experiments. Additionally, Dugourd et al 
recently reported the optical spectra and photodissociation patterns of different $\mathrm{Hp}$ oligosaccharides under UV irradiation. ${ }^{[34,35]}$ In terms of fragmentation pathway, it was also observed that UVPD spectra were more informative than CID due to additional cross-ring cleavages that provide information about the sulfate group location. An intense broad band centered at $240 \mathrm{~nm}$ was detected in the optical photodissociation spectrum of sulfated disaccharides in the UV range. Theoretical work recently reported by the same group by means of time-dependent density functional theory (TD-DFT) lead to the assignment of this prominent band to a $\pi-\pi^{*}$ excitation involving the $\mathrm{COOH}$ groups and the adjacent $\mathrm{C}=\mathrm{C}$ double bonds. ${ }^{[36]}$

As already reported by Saad and coworkers, ${ }^{[37]}$ upon CID activation, the three Hp-like disaccharides IIS, IIIS and IH (Scheme 1) share the same base peak, which corresponds to the formation of the ${ }^{0,2} \mathrm{~A}_{2}$ ion. Indeed, CID spectra of IIS/IIIS disaccharides are almost identical. ${ }^{[37]}$ A few years ago, different groups have reported that the gas-phase reactivity of metal ions can help in differentiating isomeric saccharides. ${ }^{[38-46]}$ Under ESI conditions, it was shown that metal ions can react with isomeric monosaccharides or disaccharides to form, according to the metal ion, $\left[\mathrm{M}(\text { saccharide })_{\mathrm{n}}\right]^{+},\left[\mathrm{M}(\text { saccharide })_{\mathrm{n}}\right]^{2+},\left[\mathrm{M}(\text { saccharide })_{\mathrm{n}} \mathrm{X}\right]^{+}$ $(\mathrm{X}=$ halogen $)$ or $\left[\mathrm{M}(\text { saccharide })_{\mathrm{n}},-\mathrm{H}\right]^{+}$complexes $(\mathrm{n} \geq 1)$, which display different fragmentation patterns than non-metallated saccharides.

In the present work, we combine both experimental techniques (CID and UVPD) with theoretical approaches (DFT and TD-DFT) to study the structure and fragmentation of calcium-cationized I-H, II-S and III-S Hp isomers. The primary goal of this work is to provide new insights about Hp /calcium interaction.

\section{Methods}

\subsection{Chemicals}


Hp disaccharides (Scheme 1) were obtained from Dextra Laboratories, (Reading, UK). Calcium chloride $\left(\mathrm{CaCl}_{2}\right)$ was purchased from Fluka. All chemicals were used without any further purification. Hp solutions were prepared at a concentration of $100 \mu \mathrm{M}$ in $\mathrm{H}_{2} \mathrm{O} / \mathrm{MeOH}$ $(50: 50 \mathrm{v} / \mathrm{v}) . \mathrm{Hp}$-calcium mixtures were prepared with a $1 / 1$ metal/sugar ratio in $\mathrm{H}_{2} \mathrm{O} / \mathrm{MeOH}$ $(50: 50 \mathrm{v} / \mathrm{v})$. Sample solutions were submitted to electrospray ionization (ESI) in negative-ion mode.

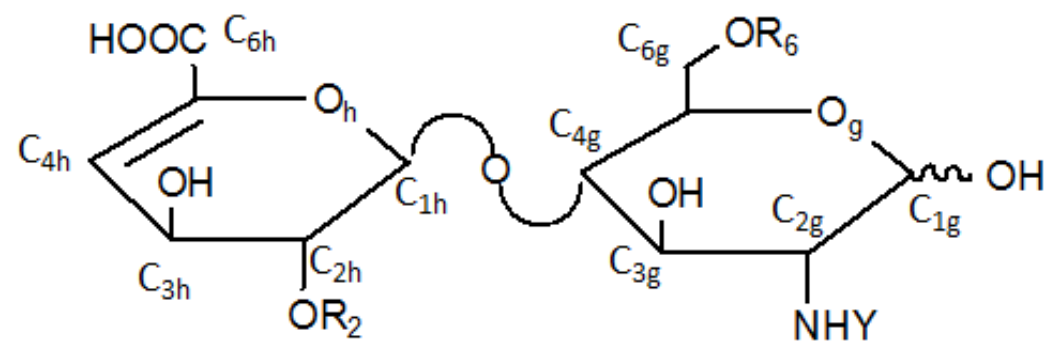

\begin{tabular}{|c|c|c|c|c|c|c|}
\hline \multicolumn{3}{|c|}{ Dissacharide } & $\mathbf{R}_{2}$ & $\mathbf{R}_{6}$ & $\mathrm{Y}$ & $\mathrm{m} / \mathrm{z}$ \\
\hline $\mathrm{A}$ & $\mathrm{I}-\mathrm{H}$ & $\Delta \mathrm{UA2S} \rightarrow$ GlcNS6S & $\mathrm{SO}_{3}$ & $\mathrm{SO}_{3}$ & $\mathrm{H}$ & $247.7^{2-}$ \\
\hline $\mathrm{B}$ & II-S & $\Delta \mathrm{UA} \rightarrow$ GIcN6S & $\mathrm{H}$ & $\mathrm{SO}_{3}$ & $\mathrm{SO}_{3}$ & $247.7^{2-}$ \\
\hline $\mathrm{C}$ & III-S & $\Delta$ UA2S $\rightarrow$ GICNS & $\mathrm{SO}_{3}$ & $\mathrm{H}$ & $\mathrm{SO}_{3}$ & $247.7^{2-}$ \\
\hline
\end{tabular}

Scheme 1: chemical structures of each Hp-derived saccharide studied in this work

\subsection{Mass spectrometry and UV Optical spectra}

The experimental setup used during this study was described in details elsewhere. ${ }^{[47]}$ Briefly, ESI mass spectra were recorded with a commercial linear quadrupole ion trap (LTQ; Thermo Fisher Scientific, San Jose, CA, USA) coupled to a UV laser beam (PantherEx OPO pumped at $355 \mathrm{~nm}$ by a SureliteII Nd:YAG, Continuum, Santa Clara, CA, USA). The OPO beam is aligned and refocused with a series of pinholes and lenses before injection on axis in the linear trap. The OPO beam diameter within the ion trap is estimated to be $1.5 \mathrm{~mm}$. A mechanical shutter electronically synchronized with the mass spectrometer allows ions to be selectively irradiated (shutter open) after mass isolation in the ion trap, during the activation time. 
For UV experiments, precursor ions were isolated in the trap, and activated (with excitation amplitude set to $0 \%$ ) for $500 \mathrm{~ms}$ in order to allow 5 laser pulses in the trap. After irradiation, the resulting mass spectrum was recorded. Fragmentation spectra were recorded for wavelengths ranging from 220 to $270 \mathrm{~nm}$. The photodissociation yield is given by $\log (($ precursor + fragments $) /$ precursor $) / \lambda \mathrm{P}_{\lambda}$, where $\lambda$ is the laser wavelength and $\mathrm{P}_{\lambda}$ is the laser power measured at the entrance of the mass spectrometer.

Low-energy CID experiments were performed within the same instrument. Helium was used as collision gas and normalized collision energy (NCE) was varied from $0 \%$ to $18 \%$. The precursor isolation width for both UVPD and CID experiments, was 3 Da. A total of 25 microscans were averaged to produce a spectrum.

\subsection{Computational details}

Conformational analysis was required for identification of low-energy structures for the three disaccharides studied. Moreover, initial optimizations at lower level of theory shortened the overall computational time and provided better starting structures for higher-level calculations. Considering the substantial size of these molecules, a "metal-free" conformational search was first performed with the molecular modeling program Spartan, using the semi-empirical PM3 method. ${ }^{[48]}$ From all PM3 calculated geometries, only structures with relative energies less than $50 \mathrm{~kJ} / \mathrm{mol}$ above minimum were then submitted to DFT-level optimization. Final geometries as well as $\mathrm{Ca} / \mathrm{Hp}$ structures were both calculated with the B3LYP hybrid functional ${ }^{[49,50]}$ as implemented in Gaussian03. ${ }^{[51]}$ They were first optimized with the $6-311 \mathrm{G}^{* *}$ basis set. Harmonic vibrational spectra and zero-point vibrational energies (ZPVE) of optimized structures were computed at that level. Relative energies were further refined with a larger basis set $(6-311++\mathrm{G}(3 \mathrm{df}, 2 \mathrm{p}))$.

UV absorption spectra were calculated for the two most stable geometries for [I-H, $-2 \mathrm{H}]^{2-}$, [II$\mathrm{S},-2 \mathrm{H}]^{2-},[\mathrm{III}-\mathrm{S},-2 \mathrm{H}]^{2-},[\mathrm{Ca}(\mathrm{I}-\mathrm{H}),-3 \mathrm{H}]^{-},[\mathrm{Ca}(\mathrm{II}-\mathrm{S}),-3 \mathrm{H}]^{-}$and $[\mathrm{Ca}(\mathrm{III}-\mathrm{S}),-3 \mathrm{H}]^{-}$species, with 
TD-DFT using the CAM-B3LYP functional in conjunction with the $6-311++\mathrm{G}^{* *}$ basis set ${ }^{[52]}$, 100 singlet excited states being included in TD-DFT calculation.

\section{Results}

\subsection{Computational study}

Throughout this paper, relative energies are expressed in $\mathrm{kJ} / \mathrm{mol}$. More detailed information about all structures mentioned in this work is available from authors upon request.

\subsubsection{Uncomplexed disaccharides}

Although we do not report detailed results for PM3 calculations, we have noticed that geometries computed at this level are generally in good agreement with DFT results. Remarkably, the various geometries calculated at the DFT level are also very close in terms of relative energy $(<50 \mathrm{~kJ} / \mathrm{mol})$. On the other hand, the relative energy ordering changes with the level of calculation. This means that, for identification of low-energy conformations for these large molecules, the systematic search using PM3 semi-empirical calculations is actually a valuable approach. Nevertheless, due to the importance of the intramolecular hydrogen bonds on the structure of carbohydrates, DFT seems essential in order to refine relative energies. The most stable structures for each disaccharide are summarized and detailed in supporting information (SI-1).

For all the three disaccharides studied here, the calculated energy strongly depends on the following parameters: (i) number and position of the hydrogen bonds, (ii) separation between negative moieties and (iii) two torsional angles: $\pi\left(\mathrm{O}_{\mathrm{h}} \mathrm{C}_{1 \mathrm{~h}} \mathrm{O}_{\mathrm{gly}} \mathrm{C}_{4 \mathrm{~g}}\right)$ and $\psi\left(\mathrm{C}_{1 \mathrm{~h}} \mathrm{O}_{\mathrm{gly}} \mathrm{C}_{4 \mathrm{~g}} \mathrm{C}_{5 \mathrm{~g}}\right)$ which characterize the relative orientation of both sugar units. ${ }^{[53]}$

The most stable structures are stabilized by several hydrogen bonds. However, three of them are common to all three Hp structures. Two involve the $\mathrm{O}_{3 \mathrm{~g}}$ hydroxyl group of glucosamine, together with either the carboxylate or the sulfate group: $\mathrm{COOH} \rightarrow \mathrm{O}_{3 \mathrm{~g}}$ and $\mathrm{O}_{3 \mathrm{~g}} \rightarrow \mathrm{SO}_{3}\left(\mathrm{R}_{6} / \mathrm{Y}\right)$. 
The third common hydrogen bond is located between the $\mathrm{O}_{3 \mathrm{~h}} \mathrm{H}$ hydroxyl group of uronic acid and the second sulfate group $\mathrm{O}_{3 \mathrm{~h}} \rightarrow \mathrm{SO}_{3}\left(\mathrm{R}_{2} / \mathrm{R}_{6}\right)$.

\subsubsection{Structure of cationized Hps}

Experimentally, negatively charged $[\mathrm{Ca}(\mathrm{Hp}),-3 \mathrm{H}]^{-}$complexes were detected. In addition to the two deprotonated sulfonate groups, Hp must therefore undergo additional deprotonation. Table 1 shows the relative energies of different forms of the $[\mathrm{M}-3 \mathrm{H}]^{3-}$ pseudo-molecular ion of I-H. From this comparison, one can see that the carboxylic group is much more acidic than the hydroxyl groups. The mesomeric stabilization of the carboxylate form via the neighbouring $\mathrm{C}=\mathrm{C}$ double bond probably partly explains the amplitude of the energy difference. This energy difference between the various structures is indeed relatively high: $156.7 \mathrm{~kJ} / \mathrm{mol}$ when the third deprotonation occurs on the $\mathrm{O}_{3 \mathrm{~h}}$ hydroxyl, $44.8 \mathrm{~kJ} / \mathrm{mol}$ for the $\mathrm{O}_{3 \mathrm{~g}}$ hydroxyl and $100.0 \mathrm{~kJ} / \mathrm{mol}$ when deprotonation takes place on the anomeric hydroxyl $\left(\mathrm{O}_{1 \mathrm{~g}}\right)$. Due to this important energy gap, we have only considered $[\mathrm{Hp}-3 \mathrm{H}]^{3-}$ structures involving a deprotonated carboxylic group, and coordination of $\mathrm{Ca}^{2+}$ to the various basic sites of those structures.

The most stable structures for each disaccharide are shown in Figure 1. The various $[\mathrm{Ca}(\mathrm{Hp}),-3 \mathrm{H}]^{-}$structures are detailed in Supporting information (SI-2). We have noticed that, when one of the negative moieties is not linked to the metal, the resulting complex is generally rather unstable. It turns out that the most stable structures have both sulfate groups and the carboxylate group interacting with $\mathrm{Ca}^{2+}$. This results in rather rigid structures and the number of intramolecular hydrogen bonds is significantly reduced as compared to the anionic counterparts.

Our results point out the critical role of the carboxylic moiety in terms of relative energy. Complexes in which $\mathrm{COO}^{-}$does not interact with $\mathrm{Ca}^{2+}$ lie $95 \mathrm{~kJ} / \mathrm{mol}, 136 \mathrm{~kJ} / \mathrm{mol}$ and 76.1 $\mathrm{kJ} / \mathrm{mol}$ above the global minimum for I-H, II-S and III-S complexes, respectively. Moreover, 
these DFT results are in good agreement with the previous data reported by Chevalier and coworkers. ${ }^{[5,14]}$ Similarly, these results confirm that the COOH group together with the $\mathrm{R}_{6}$ and NHY moieties of glusosamine, play a critical role in the interaction with $\mathrm{Ca}^{2+}$ ions.

Binding energy values $(\mathrm{BE})$ of $\approx 2450 \mathrm{~kJ} / \mathrm{mol}$ were estimated. These values are not particularly surprising since we deal here with triply-deprotonated species. Given these BEs, it seems reasonable to postulate that the metal ion strongly stabilizes the bound structure, hence decreasing the possibility for structural changes within $\mathrm{Hp}$ disaccharides after complexation to $\mathrm{Ca}^{2+}$.

\subsection{Mass spectrometry}

\subsubsection{MS/MS spectra of uncomplexed Hp isomers}

We have used the nomenclature proposed by Domon and Costello to label the fragment ions detected experimentally. ${ }^{[54]}$ Three main types of dissociation patterns were observed in the product ion mass spectra: (i) neutral loss of small molecules $\left(\mathrm{H}_{2} \mathrm{O}\right.$ and $\left.\mathrm{SO}_{3}\right)$, (ii) glycosidic bond cleavages, (iii) cross ring cleavages. $[\mathrm{Hp},-2 \mathrm{H}]^{2-}$ CID spectra (see section SI-3 of the Supporting Information) are similar to those previously reported by Saad et al. ${ }^{[37]}$ The three CID spectra are dominated by the formation of ${ }^{0,2} \mathrm{~A}_{2}$ and complementary ${ }^{0,2} \mathrm{X}_{0}$ cross-ring ions. Globally upon CID, fragmentation spectra of doubly deprotonated disaccharides are distinguishable, but those of $[\mathrm{II}-\mathrm{S},-2 \mathrm{H}]^{2-}$ and $[\mathrm{III}-\mathrm{S},-2 \mathrm{H}]{ }^{2-}$ are similar. A comparative table of fragments was already reported by Saad et al. ${ }^{[37]}$ and is presently given in comparison with UVPD spectra (vide infra).

\subsubsection{MS/MS spectra of calcium-cationized dissacharides}

MS/MS spectra of the three $[\mathrm{Ca}(\mathrm{Hp}),-3 \mathrm{H}]^{-}$complexes $(\mathrm{m} / \mathrm{z} 534)$ are given in Figure 2 (charts a-b-c), while the different fragment ions are summarized in Table 2. Our results show that I-H/II-S/III-S disaccharides can be unambiguously distinguished thanks to their interaction 
with $\mathrm{Ca}^{2+}$ ions. Each $[\mathrm{Ca}(\mathrm{Hp}),-3 \mathrm{H}]^{-}$complex $(\mathrm{m} / z$ 534) indeed exhibits a totally different dissociation pattern. Two kinds of fragment ions are encountered: (i) calcium-containing fragments, indicated with “*” $\left(\mathrm{CaX}^{-*}+\mathrm{Y}\right)$ and (ii) calcium-free fragments $\left(\mathrm{X}^{-}+\mathrm{CaY}\right)$ where the metal is part of the neutral loss.

In comparison with CID spectra of $[\mathrm{Hp},-2 \mathrm{H}]^{2-}$, MS/MS spectra of $[\mathrm{Ca}(\mathrm{Hp}),-3 \mathrm{H}]^{-}$complexes display a significantly lower amount of product ions. This is particularly true for the $[\mathrm{Ca}(\mathrm{III}-\mathrm{S}),-3 \mathrm{H}]^{-}$complex. The strong ionic interaction between metal and anionic moieties in Hp (vide supra) strongly reduces the flexibility of $\mathrm{Hp}$, which may result in the remarkable decrease in the number of product ions. It is also possible that the fragments generated during CID may remain attached to the metal due to this strong ionic interaction. Consistently, it is observed less elimination of entire sugar units (generally associated with glycosidic bond cleavages), suggesting that the metal should interact with both the glucosamine and the hexauronic acid rings, as previously shown by our DFT calculations.

The MS/MS spectrum of the I-H/Ca complex (Figure 2a) shows one dominating fragment ion at $m / z 475$, attributed to the ${ }^{0,2} \mathrm{~A}_{2} *$ cross-ring cleavage. Moreover, fragments ${ }^{0,2} \mathrm{X}_{1} *$ and ${ }^{0,2} \mathrm{X}_{1} /{ }^{0,2} \mathrm{~A}_{2} *$ are observed at $m / z 418$ and 359 , respectively. According to these fragmentation patterns, the metal should interact, prior to dissociation, with both $\mathrm{R}_{2}$ and $\mathrm{R}_{6}$ sulfate groups. Moreover, the detection of $\mathrm{B}_{1} *$ and $\mathrm{Y}_{1}$, detected at $\mathrm{m} / \mathrm{z} 237$ and $\mathrm{m} / \mathrm{z} 258$, respectively, also suggest a metal interacting with both $\mathrm{R}_{2}$ and $\mathrm{COO}^{-}$groups. The three deprotonated sites may thus be involved in the interaction with the metal, as encountered in the global minimum deduced from our DFT study (See section SI-2 of the Supporting Information).

In the case of II-S (Figure 2b), the most abundant product ion observed is $\mathrm{m} / \mathrm{z} 316$, corresponding to ${ }^{2,4} \mathrm{X}_{0} *$. Detection of ${ }^{0,2} \mathrm{X}_{1} *$ and $\mathrm{Z}_{1} / \mathrm{H}_{2} \mathrm{O}^{*}(\mathrm{~m} / z 418$ and 340) is consistent with the metal interacting with both sulfate groups $\left(\mathrm{R}_{6}\right.$ and NHY). On the other hand, the intense calcium-free fragment ion observed at $m / z 258$ and corresponding to the $\mathrm{Y}_{1} / \mathrm{SO}_{3}$ 
fragment, as well as the peak detected at $m / z 474$, namely ${ }^{1,3} \mathrm{X}_{1}{ }^{*}$, suggest a calcium at the vicinity of the carboxylate moiety. Remarkably, the cross-ring fragment ${ }^{0,2} \mathrm{~A}_{2}$ is obtained with and without calcium, at $m / z 395\left({ }^{0,2} \mathrm{~A}_{2} *\right)$ and $m / z 357\left({ }^{0,2} \mathrm{~A}_{2}\right)$ respectively. The nature of the ${ }^{0,2} \mathrm{~A}_{2}$ ion was confirmed by $\mathrm{MS}^{3}$, whose fragmentation pattern is the same as the $\mathrm{MS}^{3}$ of the ${ }^{0,2} \mathrm{~A}_{2}$ ion generated from $[\mathrm{II}-\mathrm{S}, 2 \mathrm{H}]^{2-}$. Both suggest a proton transfer from the anomeric hydroxyl group of the glucosamine residue to the endocyclic oxygen, thus promoting the cross-ring cleavage (Scheme 2). This mechanism is consistent with the CID spectrum reported by Saad et al for $[\mathrm{II}-\mathrm{S},-2 \mathrm{H}]{ }^{2-}$, and with their data obtained by using labeled $\left({ }^{2} \mathrm{H}\right.$ and $\left.{ }^{18} \mathrm{O}\right)$ disaccharides.

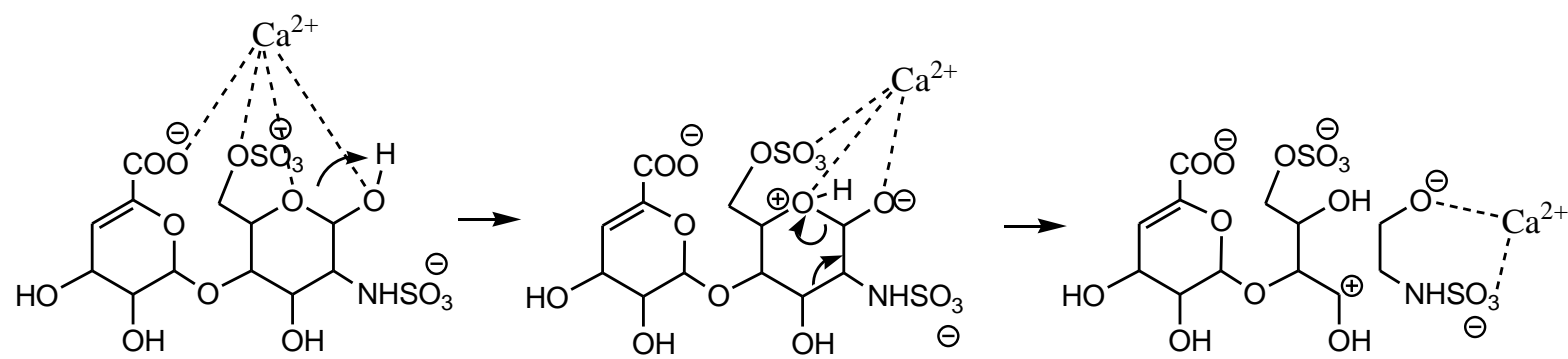

Scheme 2: Proposed mechanism for the formation of the ${ }^{0,2} \mathrm{~A}_{2}$ product ion for the [Ca(II-S), $\mathrm{H}]^{-}$complex.

Figure $2 \mathrm{c}$ shows the product ion spectrum of the $[\mathrm{Ca}(\mathrm{III}-\mathrm{S}),-3 \mathrm{H}]^{-}$complex. The spectrum is dominated by ${ }^{0,4} \mathrm{X}_{0} *(m / z 474)$ and ${ }^{0,2} \mathrm{~A}_{2}(m / z$ 357) ions. These two fragments suggest again a mechanism similar to that proposed in Scheme 2. In this case, one may also reasonably assume that at some point of the dissociation process the metal interacts with both sulfate groups ( $\mathrm{R}_{2}$ and NHY) such as in IIIS-Ca-b form (Figure SI-2), as shown in Scheme 3. This particular coordination mode should allow formation of the ${ }^{0,4} \mathrm{X}_{0} *$ ion. Then, similarly to $[\mathrm{Ca}(\mathrm{II}-\mathrm{S}),-3 \mathrm{H}]^{-}$, the same proton transfer as reported by Saad and coworkers can promote the ${ }^{0,2} \mathrm{~A}_{2}$ cross-ring cleavage. 


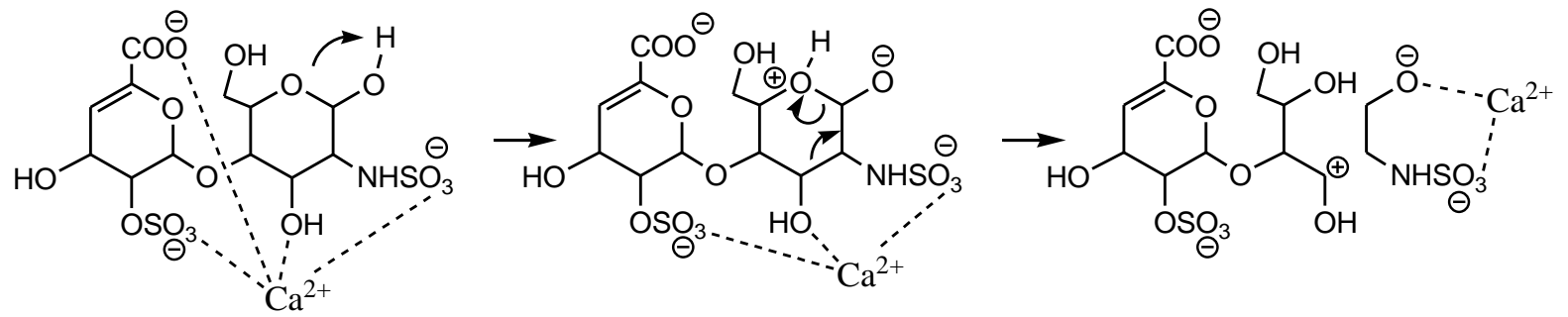

Scheme 3: Proposed mechanism for the formation of the ${ }^{0,2} \mathrm{~A}_{2}$ product ion for the [Ca(III-S), $\mathrm{H}]^{-}$complex.

Cross-ring and glycosidic bond cleavages may also give some insights about the metal binding mode. MS/MS spectra of the three complexes suggest that all the negatively charged functional groups may interact with the metal. Starting from an initial complex, change in the coordination scheme may occur during the CID process, therefore allowing different types of dissociations, as illustrated by schemes 2 and 3. However, the possibility of a mixture of structures with different coordination scheme coexisting in the gas phase cannot be rigorously discarded. The coexistence of multiple coordination modes before collision can be evaluated by comparison of relative energies for the different structures obtained by DFT. The resulting relative energies obtained with III-S neither support nor discard this assumption. On the other hand, for I-H and II-S, one binding scheme is energetically particularly favored (see Supporting Information). However, it is worth noting that due to the complexity of the systems under investigation, only partial exploration of the potential energy surface was performed.

\subsubsection{UVPD results}

UVPD spectra of $[\mathrm{Hp},-2 \mathrm{H}]^{2-}$ ions and $[\mathrm{Ca}(\mathrm{Hp}),-3 \mathrm{H}]^{-}$complexes were recorded at $240 \mathrm{~nm}$ and $220 \mathrm{~nm}$, respectively. UVPD spectra of the three $[\mathrm{Hp}-2 \mathrm{H}]^{2-}$ ions $(\mathrm{m} / \mathrm{z} 247.7)$ are given in Figure 3 (charts a-b-c), while the different fragment ions, and their comparison with CID fragments, are summarized in Table 3. 
As reported by Dugourd et al, ${ }^{[33-35]}$ UVPD activation spectra may in some cases carry more information than CID spectra, due to additional cross-ring cleavages. As a matter of fact, if one considers for example the isomer I-H (Figure 3a), additional cross-ring fragments ${ }^{0,2} \mathrm{X}_{1} / \mathrm{SO}_{3}$ or ${ }^{0,2} \mathrm{X}_{1}{ }^{2-}$ are observed (Table 3 ). Comparison of Figures $3 \mathrm{~b}$ and $3 \mathrm{c}$ shows that a better II-S/III-S discrimination is obtained by UVPD with respect to CID. However, in most cases, differences are globally not so noticeable, and particularly when considering the UVPD spectra of the $[\mathrm{Ca}(\mathrm{Hp}),-3 \mathrm{H}]^{-}$complexes (see Figure 4). For these complexes, the fragmentation yield is very low, again suggesting the perturbation of the chromophore part of the disaccharides by the metal. Both glycosidic bond cleavage and cross-ring fragments are observed in very weak abundance, but allow the three molecules to be differentiated. However, the fragments observed by UVPD were also observed by CID activation (Figure 2). Consequently, UV activation at $220 \mathrm{~nm}$ does not induce any specific fragmentation pattern for the complexes.

\subsection{Optical spectra comparison.}

In addition to UV photo-dissociation spectra, we also recorded the optical spectra of the various complexes in the 220-270 nm energy range. The spectra recorded for $[\mathrm{I}-\mathrm{H},-2 \mathrm{H}]^{2-}$ ion is presented in Figure 5a (dotted line). A broad band with a maximum at $\lambda=235 \mathrm{~nm}$ and a shoulder at $\lambda=245 \mathrm{~nm}$ are observed. The calculated spectrum for the global minimum (IH_a) displays a band at 236 and a second at $242 \mathrm{~nm}$ (solid line). As observed in Figure 5a, the agreement between theory and experiment is good. A detailed analysis of the two electronic transitions reveals that both transitions are mainly due to an excitation of $\pi-\pi^{*}$ orbital in the $\mathrm{C}=\mathrm{C}$ double bond system and also to the $\mathrm{n}-\pi^{*}$ orbital localized in the $\mathrm{COOH}$ group.

To study the influence of the metal onto the absorption spectrum, we have also carried out the same experiment on the $[\mathrm{Ca}(\mathrm{I}-\mathrm{H}),-3 \mathrm{H}]^{-}$complex, and Figure $5 \mathrm{~b}$ shows the experimental optical spectra recorded in the $220-270 \mathrm{~nm}$ energy range (in dotted line). Interestingly, three 
bands are observed for the calcium complex: a broad band in the UV of which we only observe the declining part from $220 \mathrm{~nm}$ (maybe at higher energy), a second band at $\lambda=240$ $\mathrm{nm}$ evidenced by the shoulder on the latter band, and a small but reproducible band at $\lambda=255$ nm. The calculated spectrum for the IH_Ca_a structure displays two bands; one centered at $210 \mathrm{~nm}$ and a second around $250 \mathrm{~nm}$. Surprisingly, the metal effect can be detected by an unambiguous blue-shift of the first band. Analysis of the electronic density reveals that both transitions are also due to $\pi-\pi^{*}$ and $n-\pi^{*}$ excitations from the $\mathrm{C}=\mathrm{C}$ and the $\mathrm{COO}^{-}$moieties. Moreover, a small population of the calcium orbitals was found in the anti-bonding orbital $\pi^{*}$. This should mean that $\mathrm{Ca}^{2+}$ strongly interacts with the chromophore system, hence changing the shape of the $\pi^{*}$ orbital. Due to this deformation, the $\pi^{*}$ orbital is higher in energy, resulting in the significant blue-shift effect observed.

Moreover, an opposite effect (red-shift) is observed for the small feature detected at $255 \mathrm{~nm}$ since theoretical analysis of this band shows that this transition also comes from $\pi-\pi^{*}$ and n$\pi^{*}$ excitations. The metal effect might therefore be detected by both opposite shifts. Furthermore, the band centered at $240 \mathrm{~nm}$ is in agreement with a "metal-free transition" that is in agreement with a metal which does not interact with the conjugated moiety of hexauronic acid. It may indicate that for this particular transition the $\mathrm{Ca}^{2+}$ metal is not involved. This result would suggest the co-existence of several structures exhibiting different coordination modes in the gas phase. It may be reasonable to assume one structure with the metal interacting with the carboxylate and the double bond (responsible for the blue shift effect) like in structure IH_Ca_a, and a less relevant structure with the Calcium metal not interacting with the double bond (i.e. fragment ion ${ }^{0,2} \mathrm{X}_{1}{ }^{*}$ ) and hence consistent with the metal-free transition. Note that this behavior is also observed for II-S and II-S/Ca, and for III$\mathrm{S}$ and III-S/Ca systems. Both optical spectra comparisons can be found in the Supporting information (SI-4). Experimentally, ion mobility or IRMPD experiments could be interesting tools in order to confirm the co-existence of different $\mathrm{Hp} / \mathrm{Ca}^{2+}$ structures. 


\section{Conclusions}

$\mathrm{Hp}-\mathrm{Ca}^{2+}$ interactions were investigated by using UV and by MS/MS experiments. For all the three isomers the base peak corresponds to the formation of ${ }^{0,2} \mathrm{~A}_{2}$ ion. Particularly, MS/MS of II-S/III-S are basically the same (loss of 59 Da). Nevertheless, when $[\mathrm{Ca}(\mathrm{Hp}),-3 \mathrm{H}]^{-}$are formed, then a complete change in the fragmentation pathway was observed. We therefore demonstrated that the interactions with $\mathrm{Ca}^{2+}$ ions with $\mathrm{Hp}$ result in different fragmentation patterns upon CID, and, as observed for deprotonated ions, allows isomeric Hp-like disaccharides to be differentiated. and to characterize the structure of these biomolecule. In addition, in the optical spectra, a good agreement was found in all cases between the experimental UV (recorded in the $220-270 \mathrm{~nm}$ ) and the calculated UV absorption spectra of the lowest energy isomers. While free-Ca ${ }^{2+}$ isomers present a broad band centered at $\lambda=240 \mathrm{~nm}$ attributed to $\pi-\pi^{*}$ and $n-\pi^{*}$ excitations from the $\mathrm{C}=\mathrm{C}$ and the $\mathrm{COO}^{-}$moieties, optical spectra recorded for $\mathrm{Ca} / \mathrm{Hp}$ ions reveal that these transitions are unambiguously shifted within the complexes.

In summary, the reported MS/MS and UV results in the gas phase strongly suggest that the calcium metal plays a critical role in the Hp structure. The carboxylic group of hexauronic acid, and the $\mathrm{R}_{6}$ and $\mathrm{Y}$ groups of the glucosamine moiety, seem to be essential for the interaction with the metal cation.

\section{Acknowledgements}

DO and JYS are grateful to the computational centre of the Universidad Autonoma de Madrid for computing facilities. 


\section{FIGURE AND TABLE CAPTIONS}

Figure 1: Most stable optimized conformers for $[\mathrm{Ca}(\mathrm{I}-\mathrm{H}), 3-\mathrm{H}]^{-},[\mathrm{Ca}(\mathrm{II}-\mathrm{S}),-3 \mathrm{H}]^{-}$and $[\mathrm{Ca}(\mathrm{III}-$ S), $-3 \mathrm{H}^{-}$.

Figure 2: Negative ion MS/MS spectra for a) $[\mathrm{Ca}(\mathrm{I}-\mathrm{H}),-3 \mathrm{H}]^{-}$, b) $[\mathrm{Ca}(\mathrm{II}-\mathrm{S}),-3 \mathrm{H}]^{-}$.c) $[\mathrm{Ca}(\mathrm{III}-$ $\mathrm{S}),-3 \mathrm{H}]^{-}$. Normalized collision energy for the CID was fixed at $16 \%$.

Figure 3: UVPD mass spectra for a) $\left.[\mathrm{I}-\mathrm{H},-2 \mathrm{H}]^{2-}, \mathrm{b}\right)[\mathrm{II}-\mathrm{S},-2 \mathrm{H}]^{2-}$, and c) $[\mathrm{III}-\mathrm{S},-2 \mathrm{H}]^{2-}$. UVPD were recorded at $240 \mathrm{~nm}$.

Figure 4: UVPD mass spectra for a) $[\mathrm{Ca}(\mathrm{I}-\mathrm{H}),-3 \mathrm{H}]^{-}$, b) $[\mathrm{Ca}(\mathrm{II}-\mathrm{S}),-3 \mathrm{H}]^{-}$.c) $[\mathrm{Ca}(\mathrm{III}-\mathrm{S}),-3 \mathrm{H}]^{-}$. UVPD recorded at $220 \mathrm{~nm}$.

Figure 5: Optical spectra for a) $[\mathrm{I}-\mathrm{H},-2 \mathrm{H}]^{2-}$ and b) $[\mathrm{Ca}(\mathrm{I}-\mathrm{H}),-3 \mathrm{H}]^{-}$ions, recorded between 220 and $270 \mathrm{~nm}$ energy range. Experimental measurements are represented by a dotted line. The calculated absorption spectrum computed at the CAM-B3LYP/6-311++G** level is represented by a solid line.

Table 1: Total (Hartree) and relative energies $(\mathrm{kJ} / \mathrm{mol})$ of the various forms of $[\mathrm{I}-\mathrm{H},-3 \mathrm{H}]^{3-}$.

Table 2: comparison of the MS/MS spectra of the three $[\mathrm{Ca}(\mathrm{Hp}),-3 \mathrm{H}]^{-}$complexes $(\mathrm{m} / \mathrm{z}, 534)$.

Table 3: List of product ions resulting from CID and UVPD (240nm) for all the three [Hp, $2 \mathrm{H}]^{2-}$ ions. 
Table 1: Total (Hartree) and relative energies $(\mathrm{kJ} / \mathrm{mol})$ of the various forms of $[\mathrm{I}-\mathrm{H},-3 \mathrm{H}]^{3-}$.

\begin{tabular}{lccccc}
\hline \multicolumn{1}{c}{ System } & $\mathbf{E}^{\mathbf{A}}$ & $\boldsymbol{\Delta} \mathbf{E}^{\mathbf{A}}$ & $\mathbf{Z P E}^{\mathbf{A}}$ & $\mathbf{E}_{\mathbf{2}}{ }^{\mathbf{B}}$ & $\mathbf{\Delta E}_{\mathbf{2}}{ }^{\mathbf{B}}$ \\
\hline $\mathrm{Hp}-\mathrm{H}(\mathrm{COOH})$ & -2522.027717 & 0.0 & 0.330714 & -2522.34178 & 0.0 \\
$\mathrm{Hp}-\mathrm{H}\left(\mathrm{O}_{3 \mathrm{~h}}\right)$ & -2521.962788 & 170.5 & 0.327970 & -2522.27936 & 156.7 \\
$\mathrm{Hp}-\mathrm{H}\left(\mathrm{O}_{3 \mathrm{~g}}\right)$ & -2522.005982 & 57.1 & 0.327456 & -2522.32147 & 44.8 \\
$\mathrm{Hp}-\mathrm{H}\left(\mathrm{O}_{1 \mathrm{~g}}\right)$ & -2521.984261 & 114.1 & 0.327733 & -2522.30074 & 100.0 \\
\hline
\end{tabular}

A: Optimization level: B3LYP/6-311G(d,p)

B: single point energies: B3LYP/6-311++G(3df,2p)//B3LYP/6-311G(d,p).

Table 2: comparison of the MS/MS spectra of the three $[\mathrm{Ca}(\mathrm{Hp}),-3 \mathrm{H}]^{-}$complexes $(\mathrm{m} / \mathrm{z}$ 534).

\begin{tabular}{|c|c|c|c|c|}
\hline$m / z$ & Dissociation product & I-H/Ca & II-S/Ca & III-S/Ca \\
\hline 516 & $-\mathrm{H}_{2} \mathrm{O}$ & $X$ & $X$ & $\mathrm{X}$ \\
\hline 498 & $-2 \mathrm{H}_{2} \mathrm{O}$ & & & $\mathrm{X}$ \\
\hline 504 & $-\mathrm{H}_{2} \mathrm{CO}$ & $X$ & & $X$ \\
\hline 475 & ${ }^{0,2} \mathrm{~A}_{2} *(\mathrm{I}-\mathrm{H})$ & $X$ & & \\
\hline \multirow[t]{2}{*}{474} & ${ }^{0,4} \mathrm{X}_{0} *$ & & & $X$ \\
\hline & ${ }^{1,3} \mathrm{X}_{1} *$ & & $\mathrm{X}$ & \\
\hline 457 & ${ }^{0,2} \mathrm{~A}_{2} * / \mathrm{H}_{2} \mathrm{O}$ & $\mathrm{X}$ & & \\
\hline 456 & ${ }^{1,3} \mathrm{X}_{1} * / \mathrm{H}_{2} \mathrm{O}$ & & $\mathrm{X}$ & \\
\hline 454 & $-\mathrm{SO}_{3}$ & $\mathrm{X}$ & $\mathrm{X}$ & $X$ \\
\hline 418 & ${ }^{0,2} \mathrm{X}_{1} *(\mathrm{I}-\mathrm{H}$ and III-S $)$ & $X$ & $X$ & \\
\hline 395 & ${ }^{0,2} \mathrm{~A}_{2} *(\mathrm{II}-\mathrm{S})$ & & $X$ & \\
\hline 359 & ${ }^{0,2} \mathrm{X}_{1} *{ }^{0,2} \mathrm{~A}_{2}$ & $\mathrm{X}$ & & \\
\hline 357 & ${ }^{0,2} \mathrm{~A}_{2}$ & & $X$ & $X$ \\
\hline 340 & $\mathrm{Z}_{1} / \mathrm{H}_{2} \mathrm{O}$ & & $X$ & \\
\hline 316 & ${ }^{2,4} \mathrm{X}_{0} *$ & & $\mathrm{X}$ & \\
\hline 275 & $\mathrm{~B}_{1}^{*}$ & $\mathrm{X}$ & & \\
\hline \multirow[t]{2}{*}{258} & $\mathrm{Y}_{1} / \mathrm{SO}_{3}(\mathrm{II}-\mathrm{S})$ & & $X$ & \\
\hline & $\mathrm{Y}_{1}(\mathrm{I}-\mathrm{H}$ and III-S) & $\mathrm{X}$ & & $X$ \\
\hline 237 & $\mathrm{~B}_{1}$ & $X$ & & \\
\hline
\end{tabular}


Table 3: List of product ions resulting from CID and UVPD (240nm) for all the three $[\mathrm{Hp},-2 \mathrm{H}]^{2-}$ ions.

\begin{tabular}{|c|c|c|c|c|c|c|c|}
\hline \multirow[t]{2}{*}{$m / z$} & \multirow[t]{2}{*}{ Product ions } & \multicolumn{2}{|c|}{$[\mathbf{I}-\mathbf{H},-\mathbf{- H}]^{2-}$} & \multicolumn{2}{|c|}{$[\mathrm{II}-\mathrm{S},-\mathbf{- 2 H}]^{2-}$} & \multicolumn{2}{|c|}{$[\mathrm{III}-\mathrm{S}, \mathbf{- 2 \mathrm { H }}]^{2-}$} \\
\hline & & CID & UVPD & CID & UVPD & CID & UVPD \\
\hline 357 & ${ }^{0,2} \mathrm{~A}_{2}$ & & & $\mathrm{X}$ & $\mathrm{X}$ & $\mathrm{X}$ & $\mathrm{X}$ \\
\hline 300 & ${ }^{0,2} \mathrm{X}_{1} / \mathrm{SO}_{3}$ & & $\mathrm{X}$ & $\mathrm{X}$ & $X$ & $X$ & $\mathrm{X}$ \\
\hline 258 & $\begin{array}{c}\mathrm{Y}_{1}(\mathrm{I}-\mathrm{H} \text { and III-S) } \\
\mathrm{Y}_{1} / \mathrm{SO}_{3}(\mathrm{II}-\mathrm{S})\end{array}$ & $X$ & $\mathrm{X}$ & $X$ & $\mathrm{X}$ & $\mathrm{X}$ & $\mathrm{X}$ \\
\hline 255 & $\mathrm{C}_{1}$ & $\mathrm{X}$ & $\mathrm{X}$ & & & $\mathrm{X}$ & \\
\hline 240 & $\begin{array}{c}\mathrm{Z}_{1} / \mathrm{SO}_{3}(\mathrm{II}-\mathrm{S}) \\
\mathrm{Z}_{1}(\mathrm{III}-\mathrm{S})\end{array}$ & & & $X$ & $\mathrm{X}$ & $X$ & \\
\hline $238.5\left(^{2-}\right)$ & $-\mathrm{H}_{2} \mathrm{O}$ & $\mathrm{X}$ & $X$ & $\mathrm{X}$ & $X$ & $\mathrm{X}$ & \\
\hline 237 & $\mathrm{~B}_{1}(\mathrm{I}-\mathrm{H}$ and III-S) & $X$ & $X$ & & & $\mathrm{X}$ & \\
\hline 222 & $\begin{array}{c}\mathrm{Z}_{1} / \mathrm{H}_{2} \mathrm{O}(\mathrm{I}-\mathrm{H} \text { and III-S) } \\
\mathrm{Z}_{1} / \mathrm{H}_{2} \mathrm{O} / \mathrm{SO}_{3}(\mathrm{II}-\mathrm{S})\end{array}$ & $X$ & $X$ & $\mathrm{X}$ & $\mathrm{X}$ & $\mathrm{X}$ & $\mathrm{X}$ \\
\hline $218\left(^{2-}\right)$ & ${ }^{0,2} \mathrm{~A}_{2}^{2-}(\mathrm{I}-\mathrm{H})$ & $\mathrm{X}$ & $\mathrm{X}$ & & & & \\
\hline $207.5\left(^{2-}\right)$ & $-\mathrm{SO}_{3}$ & & & & $X$ & & \\
\hline 199 & $\mathrm{Y}_{1} /{ }^{0,2} \mathrm{~A}_{2}(\mathrm{I}-\mathrm{H}$ and II-S $)$ & & $X$ & & $X$ & & \\
\hline $189.5\left(^{2-}\right)$ & ${ }^{0,2} \mathrm{X}_{1}^{2-}$ & & $\mathrm{X}$ & $\mathrm{X}$ & $\mathrm{X}$ & $X$ & $\mathrm{X}$ \\
\hline $168.5\left(^{2-}\right)$ & $\mathrm{Y}_{1}^{2-}$ & & & $\mathrm{X}$ & $X$ & & \\
\hline 157 & $\begin{array}{c}\mathrm{B}_{1}(\mathrm{I}-\mathrm{H} \text { and II-S }) \\
\mathrm{B}_{1} / \mathrm{SO}_{3}(\mathrm{III}-\mathrm{S})\end{array}$ & & $\mathrm{X}$ & $\mathrm{X}$ & $\mathrm{X}$ & $\mathrm{X}$ & $\mathrm{X}$ \\
\hline 138 & ${ }^{0,2} \mathrm{X}_{0}(\mathrm{II}-\mathrm{S}$ and III-S) & & & $X$ & $\mathrm{X}$ & $\mathrm{X}$ & $X$ \\
\hline 115 & ${ }^{0,2} \mathrm{~A}_{1}(\mathrm{II}-\mathrm{S})$ & & & $\mathrm{X}$ & $\mathrm{X}$ & & \\
\hline
\end{tabular}

Table 3 
a)

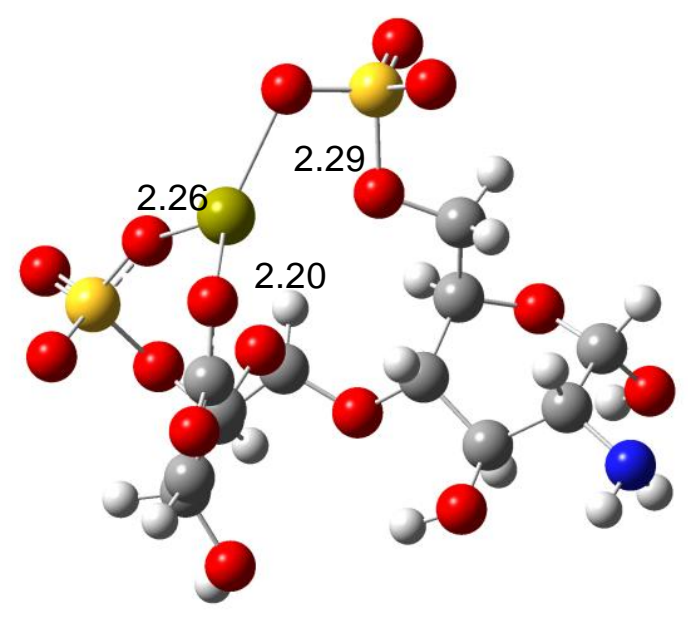

b)

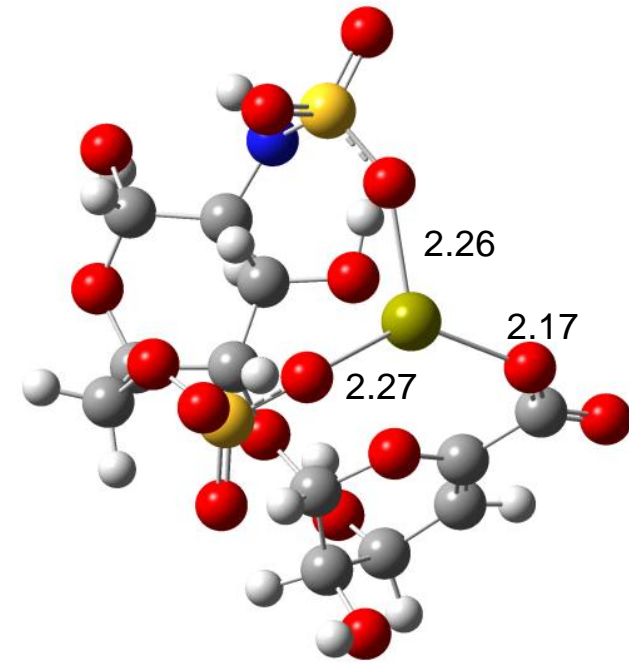

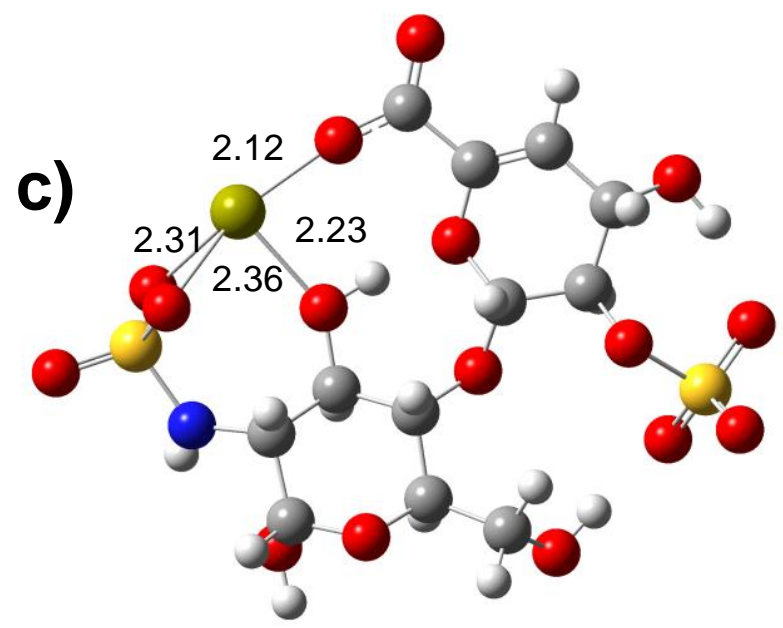

Figure 1 


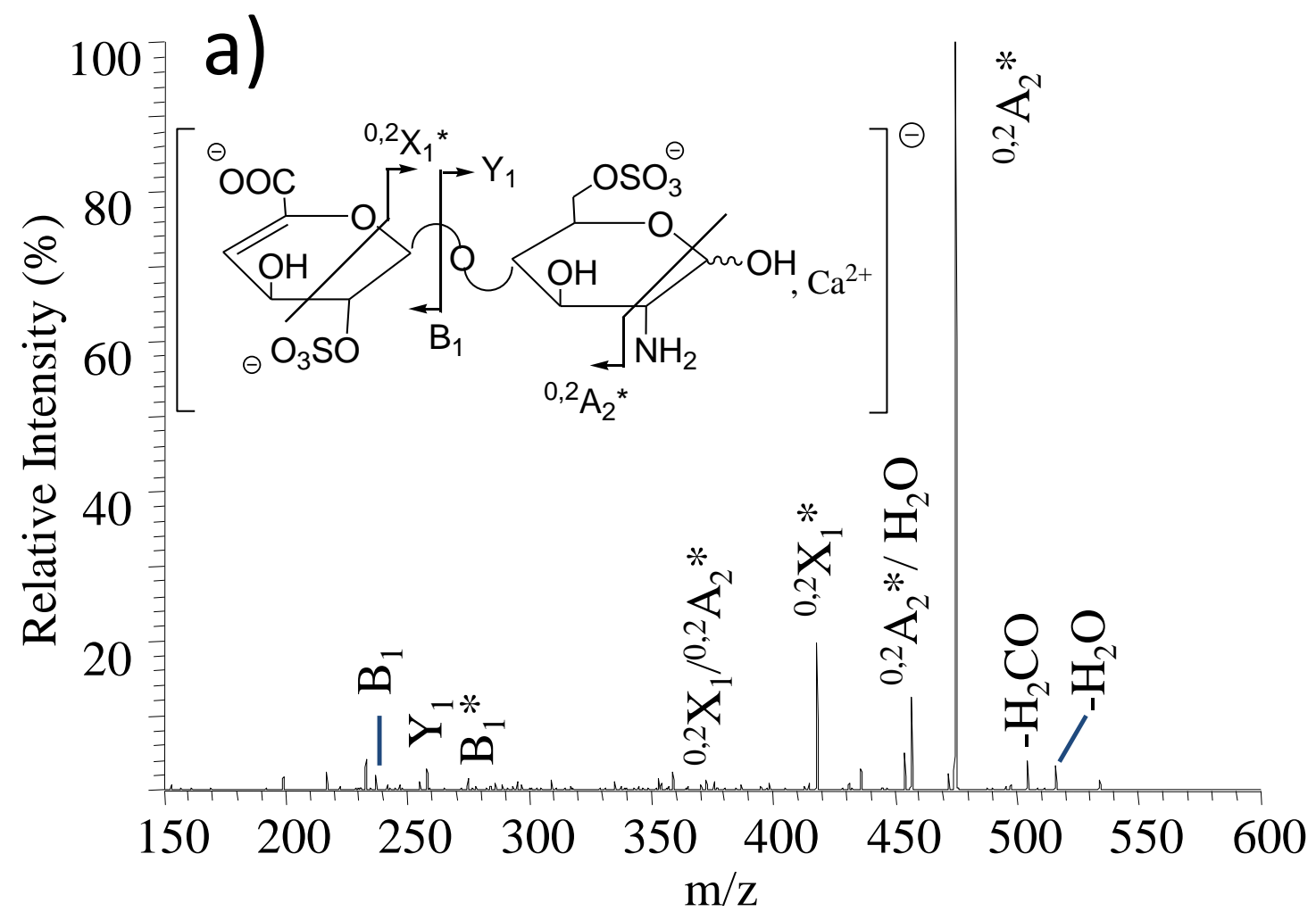

Figure 2a

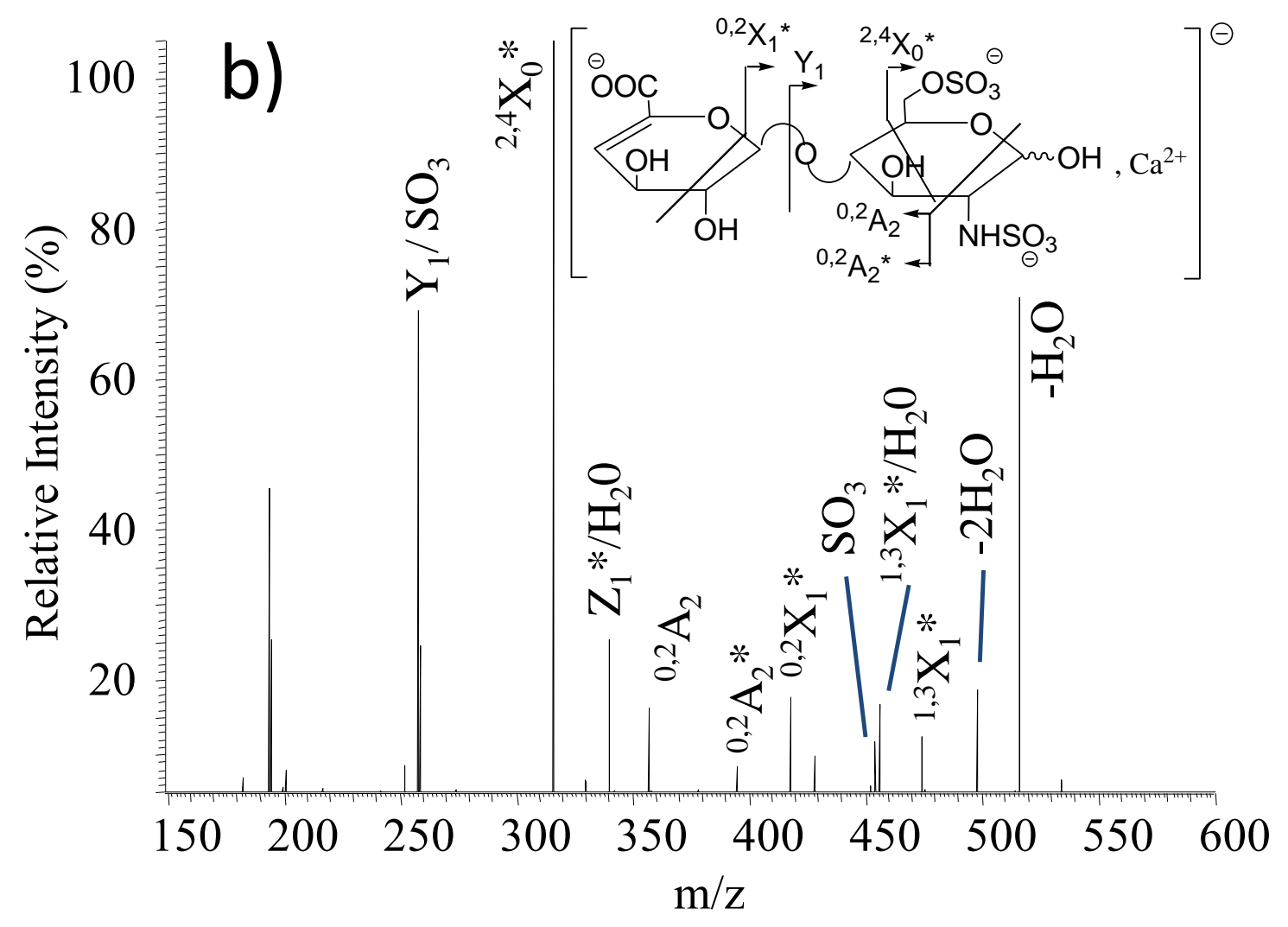

Figure 2b (continued) 


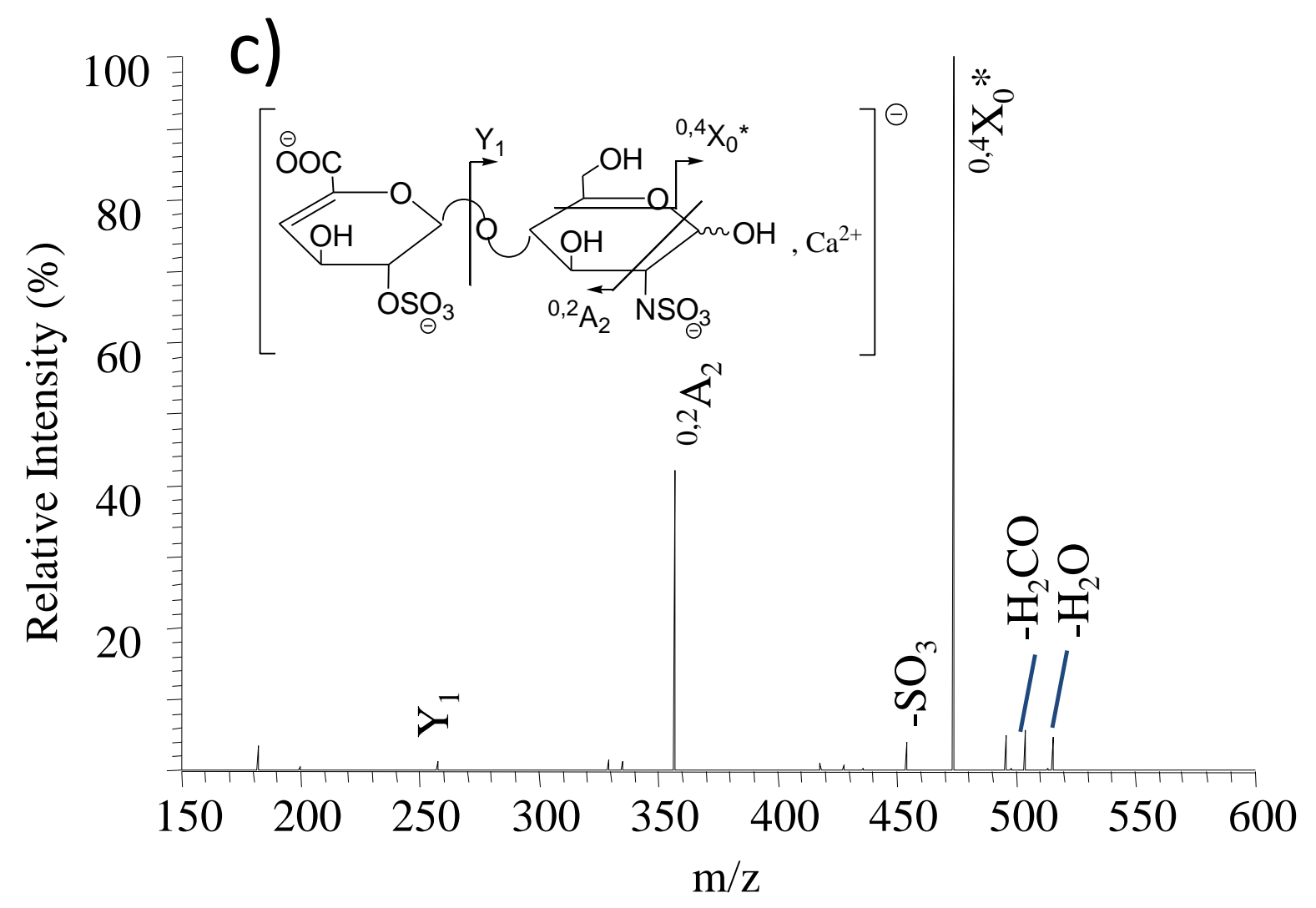

Figure 2c 


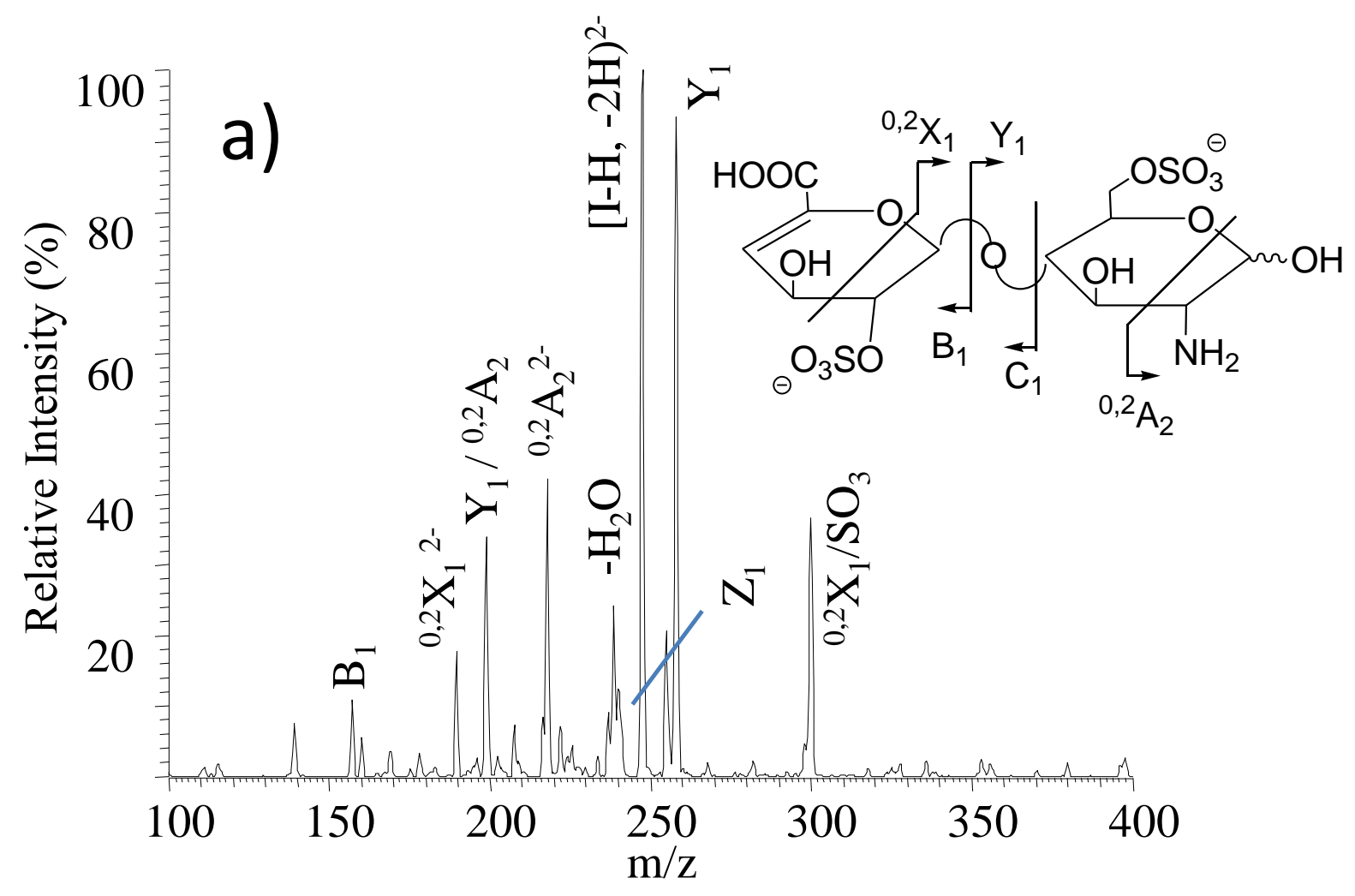

Figure 3a

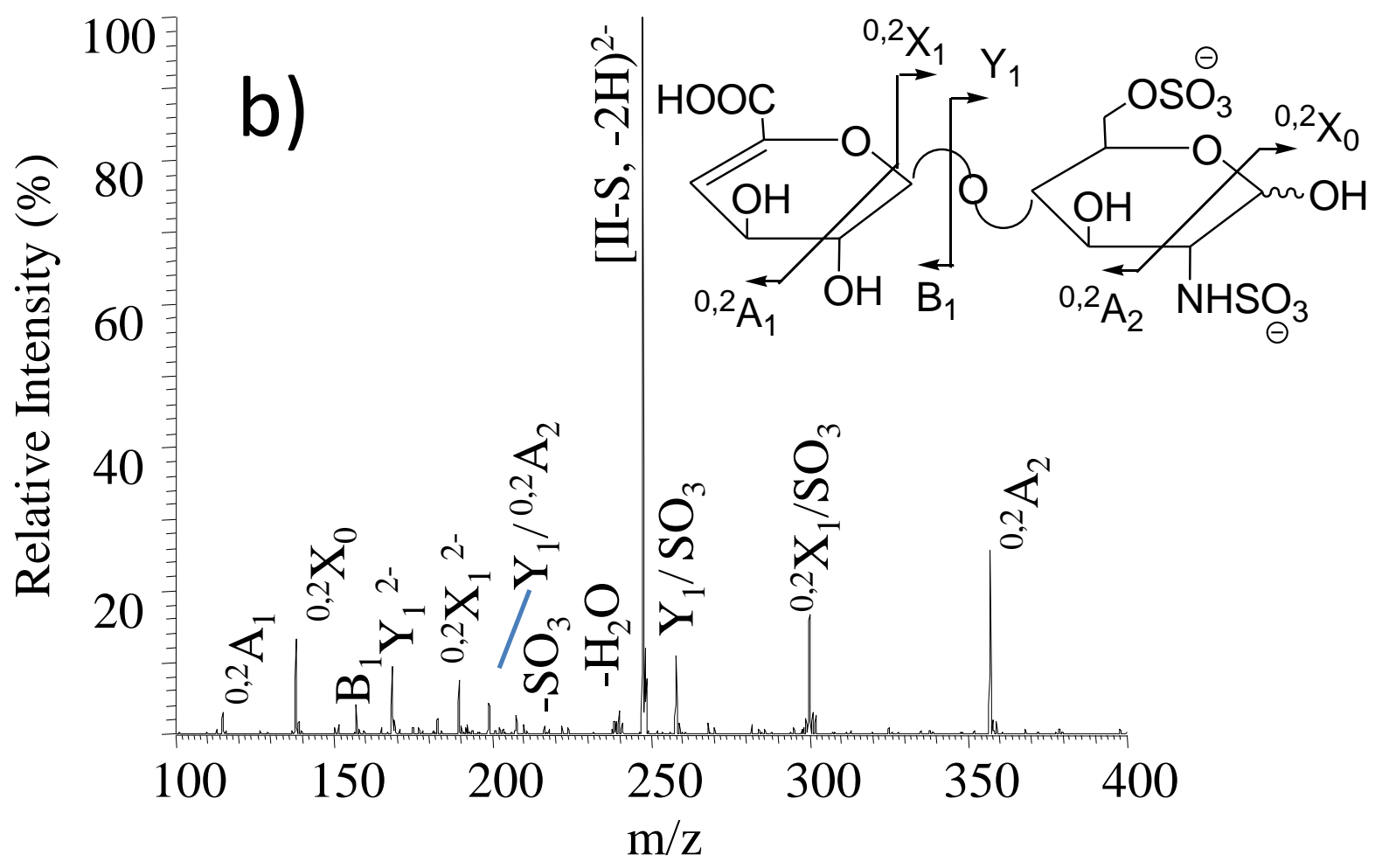

Figure 3b (Continued) 


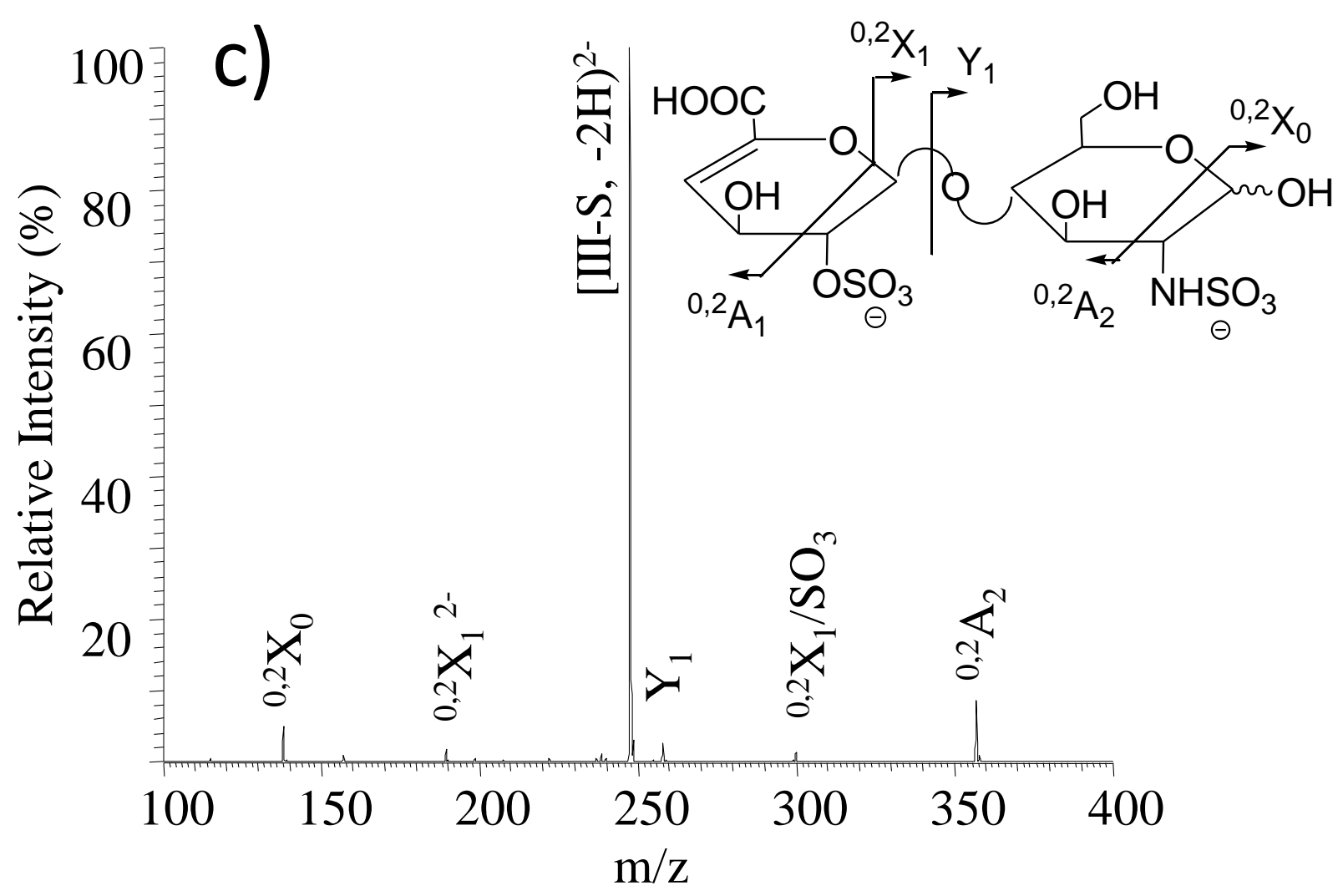

Figure 3c 


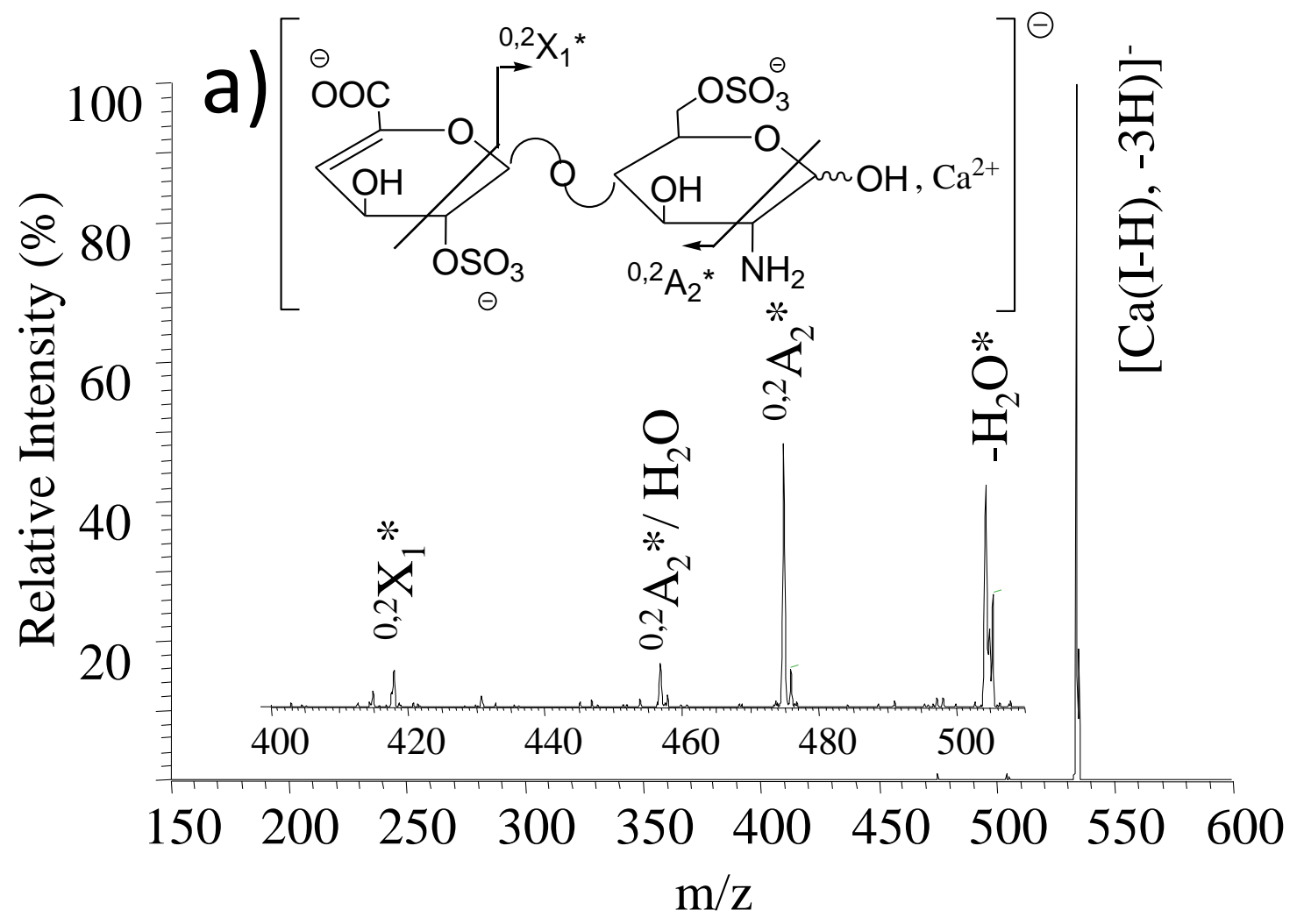

Figure 4a

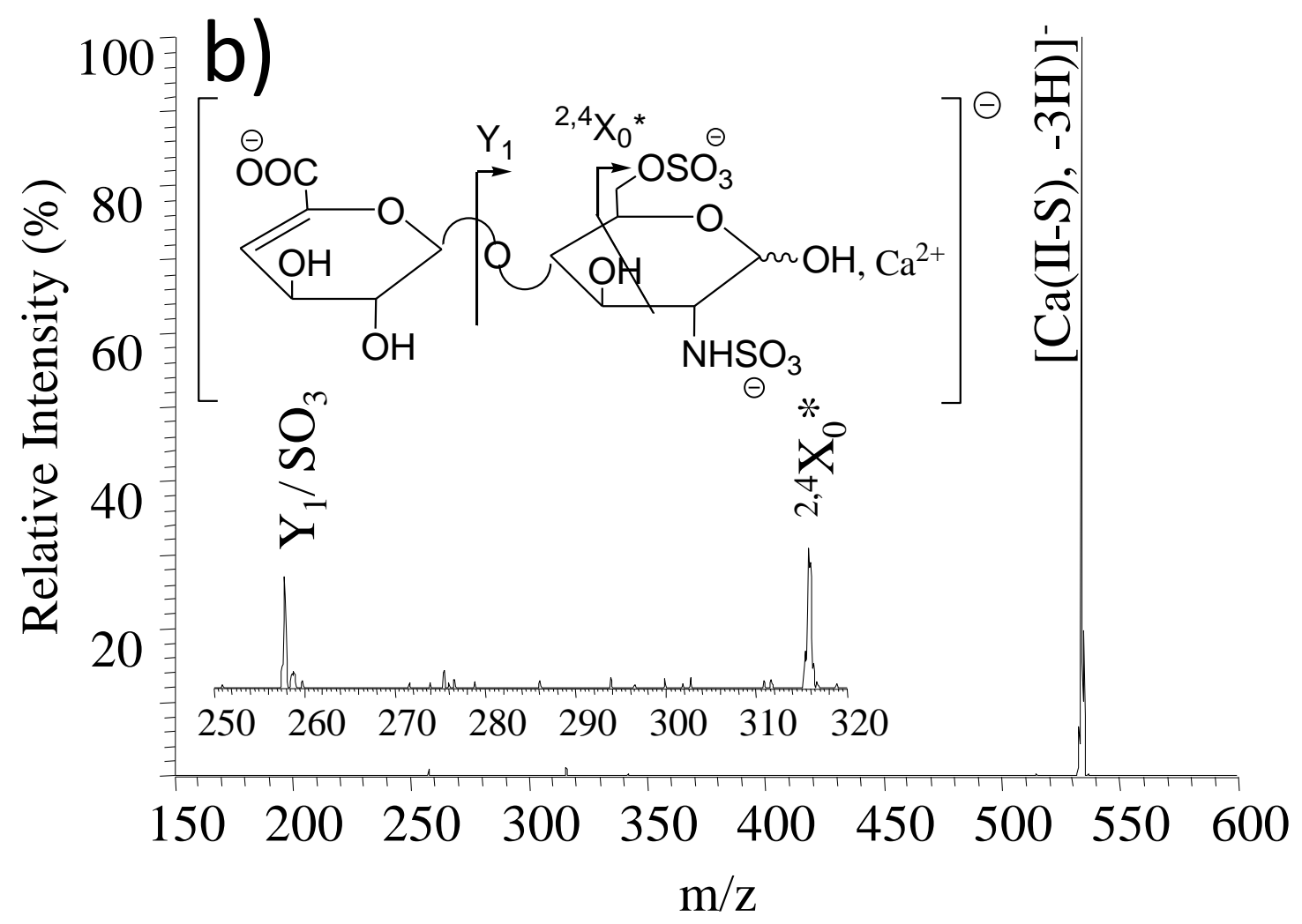

Figure 4b (continued) 


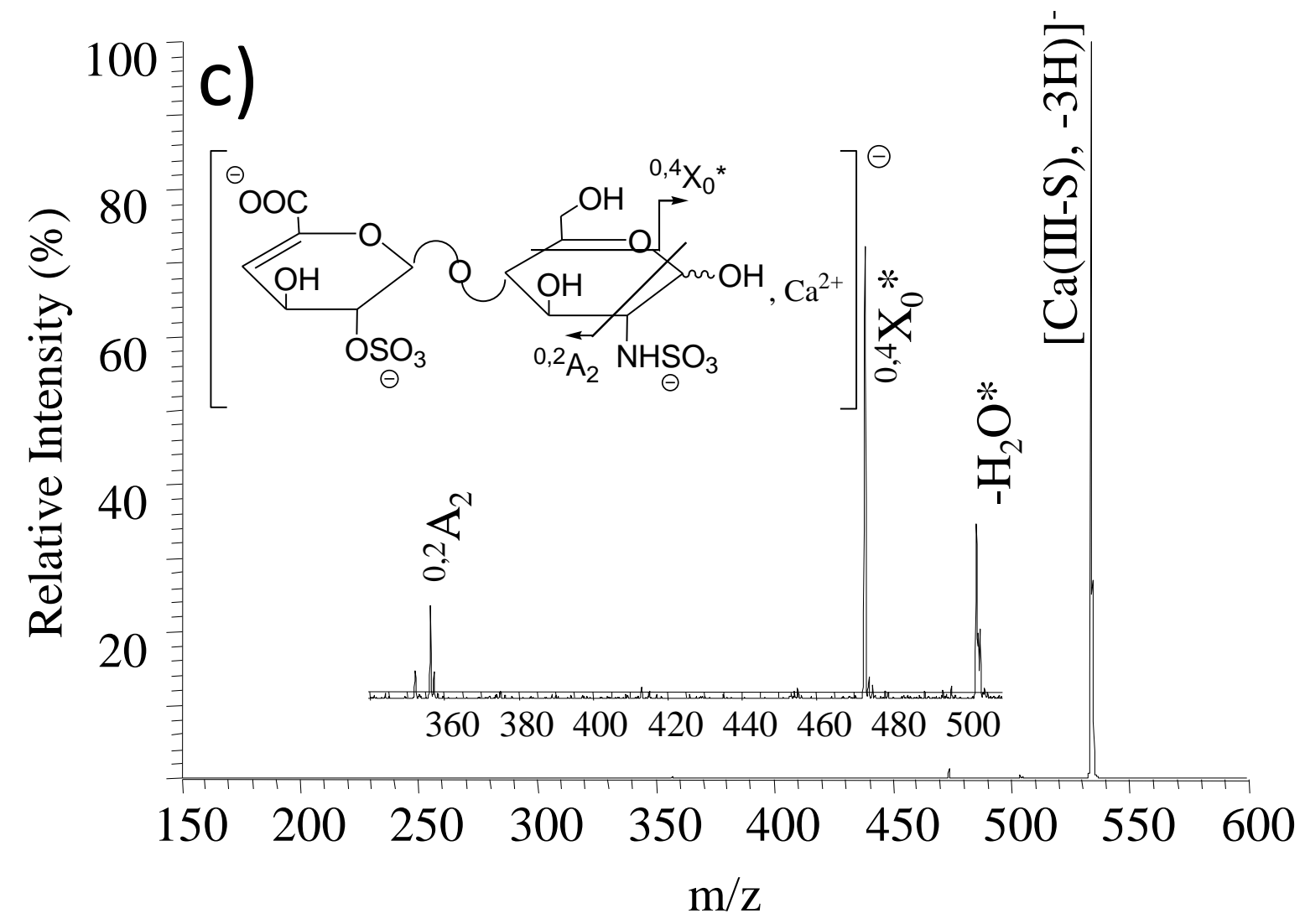

Figure 4c 

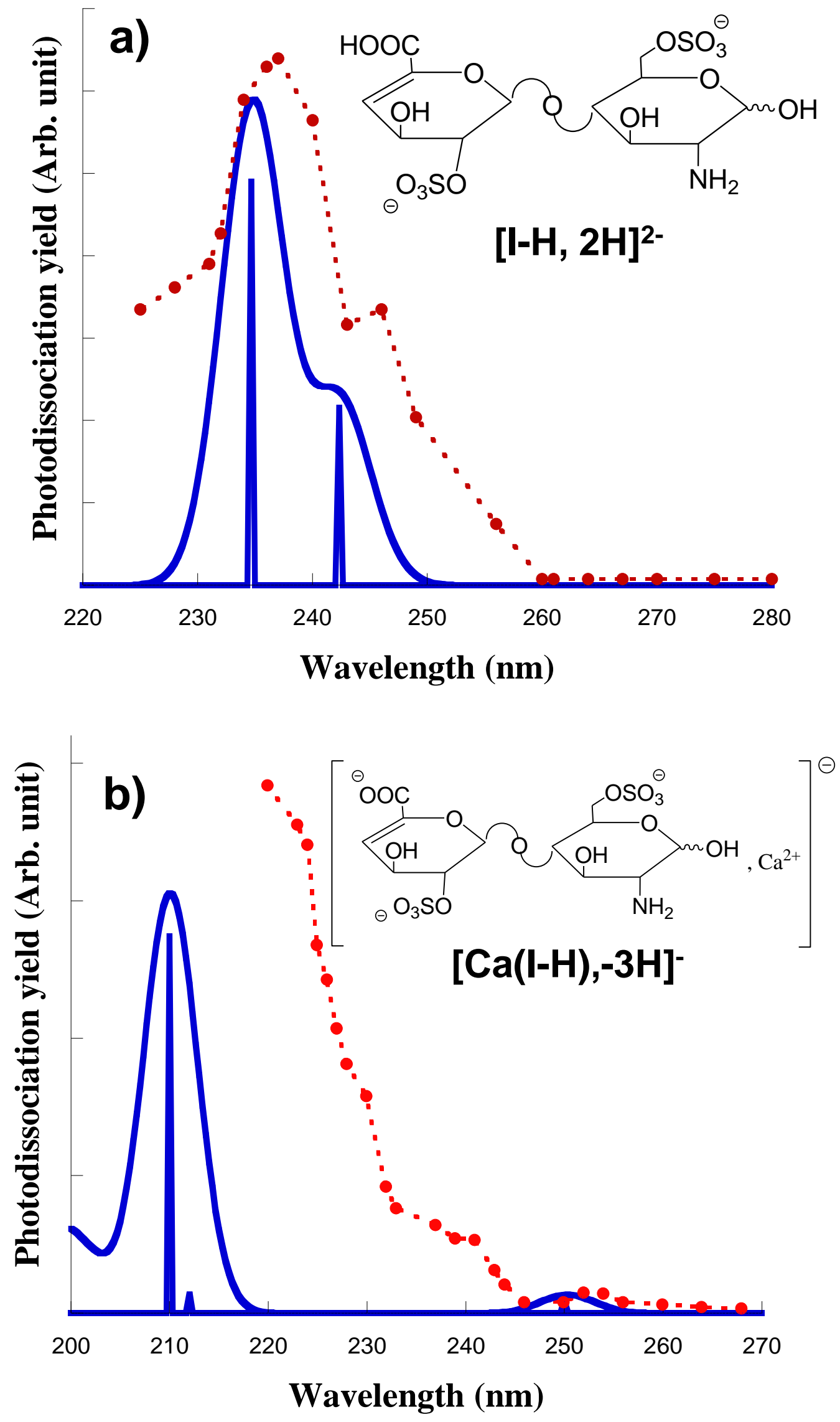

Figure 5 


\section{References}

[1] N. Perrimon, M. Bernfield, Cellular functions of proteoglycans - an overview. Semin. Cell Dev. Biol. 2001, 12, 65.

[2] I. Capila, R. J. Linhardt, Heparin - Protein interactions. Angew. Chem.-Int. Edit. 2002, 41, 391.

[3] A. K. Powell, E. A. Yates, D. G. Fernig, J. E. Turnbull, Interactions of heparin/heparan sulfate with proteins: Appraisal of structural factors and epxerimental approaches. Glycobiology 2004, 14, 17R.

[4] D. L. Rabenstein, Heparin and heparan sulfate: structure and function. Nat. Prod. Rep. 2002, 19,312 .

[5] F. Chevalier, R. Lucas, J. Angulo, M. Martin-Lomas, P. M. Nieto, The heparin-Ca(2+) interaction: the influence of the O-sulfation pattern on binding. Carbohydr. Res. 2004, 339, 975.

[6] R. F. Parrish, W. R. Fair, Selective binding of zinc ions to heparin rather than to other glycosaminoglycans. Biochem. J. 1981, 193, 407.

[7] R. Gonzalez-Iglesias, M. A. Pajares, C. Ocal, J. C. Espinosa, B. Oesch, M. Gasset, Prion protein interaction with glycosaminoglycan occurs with the formation of oligomeric complexes stabilized by $\mathrm{Cu}$ (II) bridges. J. Mol. Biol. 2002, 319, 527.

[8] S. R. Srinivasan, B. Radhakrishnamurthy, G. S. Berenson, Studies on the interaction of heparin with serum lipoproteins in the presence of $\mathrm{Ca} 2+, \mathrm{Mg} 2+$, and $\mathrm{Mn} 2+$. Arch. Biochem. Biophys. 1975, 170, 334.

[9] V. Gerke, C. E. Creutz, S. E. Moss, Annexins: Linking Ca2+ signalling to membrane dynamics. Nat. Rev. Mol. Cell Biol. 2005, 6, 449.

[10] V. Gerke, S. E. Moss, Annexins: From structure to function. Physiol. Rev. 2002, 82, 331.

[11] I. Capila, M. J. Hernaiz, Y. D. Mo, T. R. Mealy, B. Campos, J. R. Dedman, R. J. Linhardt, B. A. Seaton, Annexin V-heparin oligosaccharide complex suggests heparan sulfate-mediated assembly on cell surfaces. Structure 2001, 9, 57.

[12] D. Grant, W. F. Long, C. F. Moffat, F. B. Williamson, A study of Ca(2+)-heparin complexformation by polarimetry. Biochem. J. 1992, 282, 601 .

[13] D. L. Rabenstein, J. M. Robert, J. Peng, Multinuclear magnetic resonance studies of the interaction of inorganic cations with heparin. Carbohydr. Res. 1995, 278, 239.

[14] F. Chevalier, J. Angulo, R. Lucas, P. M. Nieto, M. Martin-Lomas, The heparin-Ca(2+) interaction: Structure of the $\mathrm{Ca}(2+)$ binding site. Eur. J. Org. Chem. 2002, 2367.

[15] D. Grant, W. F. Long, F. B. Williamson, Infrared spectroscopy of heparin-cation complexes. Biochem. J. 1987, 244, 143. 
[16] D. Grant, W. F. Long, C. F. Moffat, F. B. Williamson, Infrared spectroscopy of heparins suggests that the region $750-950 \mathrm{~cm}-1$ is sensitive to changes in iduronate residue ring conformation. Biochem. J. 1991, 275, 193.

[17] I. Stevic, N. Parmar, N. Paredes, L. R. Berry, A. K. C. Chan, Binding of Heparin to Metals. Cell Biochem. Biophys. 2011, 59, 171.

[18] Y. J. Seo, M. R. Schenauer, J. A. Leary, Biologically relevant metal-cation binding induces conformational changes in heparin oligosaccharides as measured by ion mobility mass spectrometry. Int. J. Mass Spectrom. 2011, 303, 191.

[19] J. Zaia, Mass spectrometry of oligosaccharides. Mass Spectrom. Rev. 2004, 23, 161.

[20] J. Zaia, ON-LINE SEPARATIONS COMBINED WITH MS FOR ANALYSIS OF GLYCOSAMINOGLYCANS. Mass Spectrom. Rev. 2009, 28, 254.

[21] C. Przybylski, F. Gonnet, D. Bonnaffe, Y. Hersant, H. Lortat-Jacob, R. Daniel, HABA-based ionic liquid matrices for UV-MALDI-MS analysis of heparin and heparan sulfate oligosaccharides. Glycobiology 2010, 20, 224.

[22] B. Yang, K. Solakyildirim, Y. Q. Chang, R. J. Linhardt, Hyphenated techniques for the analysis of heparin and heparan sulfate. Analytical and Bioanalytical Chemistry 2011, 399, 541.

[23] G. O. Staples, J. Zaia, Analysis of Glycosaminoglycans Using Mass Spectrometry. Current Proteomics 2011, 8, 325.

[24] C. Przybylski, F. Gonnet, W. Buchmann, R. Daniel, Critical parameters for the analysis of anionic oligosaccharides by desorption electrospray ionization mass spectrometry. J. Mass Spectrom. 2012, 47, 1047.

[25] R. R. Huang, J. Liu, J. S. Sharp, An Approach for Separation and Complete Structural Sequencing of Heparin/Heparan Sulfate-like Oligosaccharides. Anal. Chem. 2013, 85, 5787.

[26] D. J. Harvey, Analysis of carbohydrates and glycoconjugates by matrix-assisted laser desorption/ionization mass spectrometry: An update for 2009-2010. Mass Spectrom. Rev. 2014, n/a.

[27] S. T. Chen, G. R. Her, Structural analysis of isomeric chondroitin sulfate oligosaccharides using regioselective 6-O-desulfation method and tandem mass spectrometry. Analytica Chimica Acta 2014, 843, 27.

[28] E. F. Naggar, C. E. Costello, J. Zaia, Competing fragmentation processes in tandem mass spectra of heparin-like Glycosaminoglycans. J. Am. Soc. Mass Spectrom. 2004, 15, 1534.

[29] B. A. Budnik, K. F. Haselmann, R. A. Zubarev, Electron detachment fissociation of peptide di-anions: an electron hole recombination phenomenon. Chem. Phys. Lett. 2001, 342, 299.

[30] J. E. P. Syka, J. J. Coon, M. J. Schroeder, J. Shabanowitz, D. F. Hunt, Peptide and protein sequence analysis by electron transfer dissociation mass spectrometry. Proc. Nat. Acad. Sci. USA 2004, 101, 9258.

[31] K. O. Zhurov, L. Fornelli, M. D. Wodrich, U. A. Laskay, Y. O. Tsybin, Principles of electron capture and transfer dissociation mass spectrometry applied to peptide and protein structure analysis. Chem. Soc. Rev. 2013, 42, 5014. 
[32] J. J. Wolff, T. N. Laremore, H. Aslam, R. J. Linhardt, I. J. Amster, Electron-Induced Dissociation of Glycosaminoglycan Tetrasaccharides. J. Am. Soc. Mass Spectrom. 2008, 19, 1449.

[33] R. Antoine, J. Lemoine, P. Dugourd, Electron photodetachment dissociation for structural characterization of synthetic and bio-polymer anions. Mass Spectrom. Rev. 2013, doi: 10.1002/mas.21402.

[34] A. Racaud, R. Antoine, P. Dugourd, J. Lemoine, Photoinduced Dissociation of HeparinDerived Oligosaccharides Controlled by Charge Location. J. Am. Soc. Mass Spectrom. 2010, 21, 2077.

[35] A. Racaud, R. Antoine, L. Joly, N. Mesplet, P. Dugourd, J. Lemoine, Wavelength-Tunable Ultraviolet Photodissociation (UVPD) of Heparin-Derived Disaccharides in a Linear Ion Trap. J. Am. Soc. Mass Spectrom. 2009, 20, 1645.

[36] A. Racaud, A. R. Allouche, R. Antoine, J. Lemoine, P. Dugourd, UV electronic excitations in acidic sugars. Theochem-J. Mol. Struct. 2010, 960, 51.

[37] O. M. Saad, J. A. Leary, Delineating mechanisms of dissociation for isomeric heparin disaccharides using isotope labeling and ion trap tandem mass spectrometry. J. Am. Soc. Mass Spectrom. 2004, 15, 1274.

[38] S. P. Gaucher, J. A. Leary, Stereochemical differentiation of mannose, glucose, galactose, and talose using zinc(II) diethylenetriamine and ESI ion trap mass spectrometry. Anal. Chem. 1998, 70, 3009.

[39] G. Smith, A. Kaffashan, J. A. Leary, Influence of coordination number and ligand size on the dissociation mechanisms of transition metal monosaccharide complexes. Int. J. Mass Spectrom. 1999, 183, 299.

[40] S. P. Gaucher, J. A. Leary, Influence of metal ion and coordination geometry on the gas phase dissociation and stereochemical differentiation of $\mathrm{N}$-glycosides. Int. J. Mass Spectrom. 2000, 197, 139.

[41] S. Konig, J. A. Leary, Evidence for linkage position determination in cobalt coordinated pentasaccharides using ion trap mass spectrometry. J. Am. Soc. Mass Spectrom. 1998, 9, 1125 .

[42] J. Y. Salpin, J. Tortajada, Structural characterization of hexoses and pentoses using lead cationization. An electrospray ionization and tandem mass spectrometric study. J. Mass Spectrom. 2002, 37, 379.

[43] V. Carlesso, C. Afonso, F. Fournier, J. C. Tabet, Stereochemical effects from doubly-charged iron clusters for the structural elucidation of diastereomeric monosaccharides using ESI/ITMS. Int. J. Mass Spectrom. 2002, 219, 559.

[44] Y. M. Xie, C. B. Lebrilla, Infrared multiphoton dissociation of alkali metal-coordinated oligosaccharides. Anal. Chem. 2003, 75, 1590.

[45] N. C. Polfer, J. J. Valle, D. T. Moore, J. Oomens, J. R. Eyler, B. Bendiak, Differentiation of isomers by wavelength-tunable infrared multiple-photon dissociation-mass spectrometry: Application to glucose-containing disaccharides. Anal. Chem. 2006, 78, 670.

[46] A. E. Firdoussi, M. Lafitte, J. Tortajada, O. Kone, J.-Y. Salpin, Characterization of the glycosidic linkage of underivatized disaccharides by interaction with $\mathrm{Pb}(2+)$ ions. Journal of mass spectrometry: JMS 2007, 42, 999. 
[47] L. Joly, R. Antoine, M. Broyer, J. Lemoine, P. Dugourd, Electron photodetachment from gas phase peptide dianions. Relation with optical absorption properties. J. Phys. Chem. A 2008, 112,898 .

[48] M. J. S. Dewar, E. G. Zoebisch, E. F. Healy, J. J. P. Stewart, The Development and Use of Quantum-Mechanical Molecular-Models .76. Am1 - a New General-Purpose QuantumMechanical Molecular-Model. J. Am. Chem. Soc. 1985, 107, 3902.

[49] A. D. Becke, A new mixing of Hartree-Fock and local density-functional theories. J. Chem. Phys. 1993, 98, 1372.

[50] C. T. Lee, W. T. Yang, R. G. Parr, Development of the Colic-Salvetti correlation-energy formula into a functional of the electron density. Phys. Rev. B 1988, 37, 785.

[51] M. J. Frisch, G. W. Trucks, H. B. Schlegel, G. E. Scuseria, M. A. Robb, J. R. Cheeseman, J. Montgomery, J. A.;, T. Vreven, K. N. Kudin, J. C. Burant, J. M. Millam, S. S. Iyengar, J. Tomasi, V. Barone, B. Mennucci, M. Cossi, G. Scalmani, N. Rega, G. A. Petersson, H. Nakatsuji, M. Hada, M. Ehara, K. Toyota, R. Fukuda, J. Hasegawa, M. Ishida, T. Nakajima, Y. Honda, O. Kitao, H. Nakai, M. Klene, X. Li, J. E. Knox, H. P. Hratchian, J. B. Cross, V. Bakken, C. Adamo, J. Jaramillo, R. Gomperts, R. E. Stratmann, O. Yazyev, A. J. Austin, R. Cammi, C. Pomelli, J. W. Ochterski, P. Y. Ayala, K. Morokuma, G. A. Voth, P. Salvador, J. J. Dannenberg, V. G. Zakrzewski, S. Dapprich, A. D. Daniels, M. C. Strain, O. Farkas, D. K. Malick, A. D. Rabuck, K. Raghavachari, J. B. Foresman, J. V. Ortiz, Q. Cui, A. G. Baboul, S. Clifford, J. Cioslowski, B. B. Stefanov, G. Liu, A. Liashenko, P. Piskorz, I. Komaromi, R. L. Martin, D. J. Fox, T. Keith, M. A. Al-Laham, C. Y. Peng, A. Nanayakkara, M. Challacombe, P. M. W. Gill, B. Johnson, W. Chen, M. W. Wong, C. Gonzalez, J. A. Pople, in Gaussian 03, Gaussian, Inc., Wallingford,CT, 2004.

[52] T. Yanai, D. P. Tew, N. C. Handy, A new hybrid exchange-correlation functional using the Coulomb-attenuating method (CAM-B3LYP). Chem. Phys. Lett. 2004, 393, 51.

[53] B. Mulloy, M. J. Forster, Conformation and dynamics of heparin and heparan sulfate. Glycobiology 2000, 10, 1147.

[54] B. Domon, C. E. Costello, A systematic nomenclature for carbohydrate fragmentations in FAB-MS/MS spectra of glycoconjugates. Glycoconj. J. 1988, 5, 397. 